\title{
Revisiting the Political Economy of Communication
}

\author{
Nicholas Garnham* and Christian Fuchs** \\ * University of Westminster. London, UK. nicholasgarnham00@gmail.com \\ ** University of Westminster. London, UK. c.fuchs@westminster.ac.uk
}

\begin{abstract}
This paper came out of a research seminar at the University of Westminster. It revisits and discusses some of Nicholas Garnham's ideas, writings and contributions to the study of the Political Economy of Communication and reflects on the concepts, history, current status and perspectives of this field and the broader study of political economy today. The topics covered include Raymond Williams' cultural materialism, Pierre Bourdieu's sociology of culture, the debate between Political Economy and Cultural Studies, information society theory, Karl Marx's theory, and the critique of capitalism.
\end{abstract}

Keywords: political economy of communication, cultural studies, media and communication studies, cultural materialism, sociology of culture, Raymond Williams, Pierre Bourdieu, political economy vs. cultural studies, information society, Karl Marx, capitalism and communication.

\section{Editorial Introduction}

Nicholas Garnham studied English Literature at Cambridge University and worked in television as film editor and film director in the 1960s. He then joined the Polytechnic of Central London in 1972, which is now our University of Westminster. In 1974 he became the head of the newly created Department of Communications and he was involved in setting up the very first BA programme in the UK in Media Studies, which started in 1975. He is the founding editor of the journal Media, Culture and Society that was established in $1979^{1}$. In 1986 he founded the Centre for Communication and Information Studies (CCIS), a research centre at the University of Westminster, which is the equivalent of what is now the Communication and Media Research Institute (CAMRI). He remained the director of the research centre until he retired in 2002.

Nicholas Garnham made important contributions to the field of study of the political economy of information and communication. Some of his publications are The Structures of Television (Garnham 1978), The Economics of UK Television (Collins, Garnham and Locksley 1988), Capitalism and Communication (Garnham 1990), and Emancipation, the Media and Modernity (Garnham 2000a). His works have focused on and have influenced the intellectual debates on topics such as capitalism and communication, the cultural industries,

\footnotetext{
${ }^{1}$ Paddy Scannell $(2007,5)$ describes the founding of Media, Culture \& Society: "Media, Culture and Society again was Nick Garnham's idea. He pushed it through, found a publisher and invited some of us (Richard Collins, Colin Sparks and James Curran were founding editors along with myself) to be on the editorial board. It was Nick who defined the position the journal would take and that was, most simply, that whatever it was, it was not going to be Althusserian Marxism. The title of the journal wasn't even something we thought about or debated - it just seemed the most obvious title. Take Raymond Williams' Culture and Society, stick Media in front and you've got it - Nick had made a documentary about Williams when he worked at the BBC before joining us, and he was a big influence for a number of us. In taking a stance against Althusserian Marxism we were not so much defining ourselves against Birmingham as against Screen. Nick had been on the editorial board of Screen in the early 1970s and I don't know what really happened, but there was a great big row and when the dust settled, a number of people had resigned including Nick and Richard Collins. They both wanted a journal for the emerging field of Media Studies with a broader scope and less theoretically dogmatic than Screen".
} 
information and communication technologies, information society theory, media and modernity, media and telecommunications policy, public service media, the public sphere, the relationship between Cultural Studies and Political Economy in Media and Communication Studies, and the theory and sociology of culture.

The Political Economy of Communication is today an established field of study that has been institutionalised in the form of research networks such as the International Association of Media and Communication Research's (IAMCR) Political Economy Section, journals, conferences, handbooks, the regular publication of new books, chapters and articles, undergraduate and postgraduate modules, textbooks, continuous works by PhD students, etc.

The task of this paper is to discuss some of Nicholas Garnahm's contributions to this field and to discuss how he sees political economy in general and the political economy of communication in particular today. It revisits some of Garnham's ideas, writings and contributions to the study of the Political Economy of Communication and provides reflections on the concepts, history, current status and perspectives of this field and the broader study of political economy today. The topics include Raymond Williams' cultural materialism, Pierre Bourdieu's cultural sociology, the debate between Political Economy and Cultural Studies in Media and Communication Studies, information society theory, and Karl Marx's theory.

This paper is based on the research seminar "Revisiting the Political Economy of Communication: A Conversation with Nicholas Garnham" that took place at the University of Westminster. An audio-recording of this seminar is available at:

http://www.triple-c.at/index.php/tripleC/article/view/553/527

The text of this article is not a transcript of the audio-recording. The audio-recording was rather used as a foundation for writing this article. The structure of the conversation along specific topics has been kept in this text in the form of sections devoted to particular topics:

Section 2: Raymond Williams and Cultural Materialism

Section 3: Pierre Bourdieu and the Sociology of Culture

Section 4: Political Economy vs. Cultural Studies

Section 5: Information Society as Theory or Ideology

Section 6: Karl Marx and Capitalism

Section 7: Discussion

\section{Christian Fuchs}

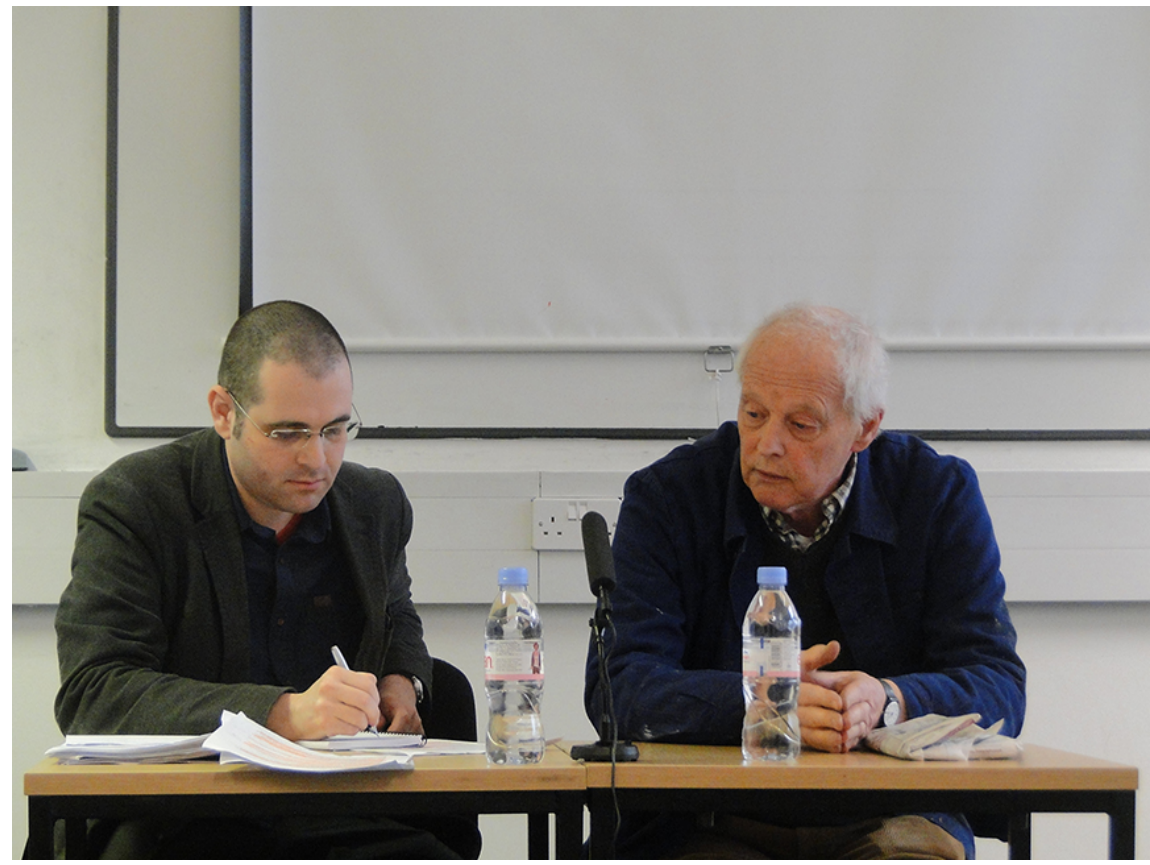




\section{Raymond Williams and Cultural Materialism}

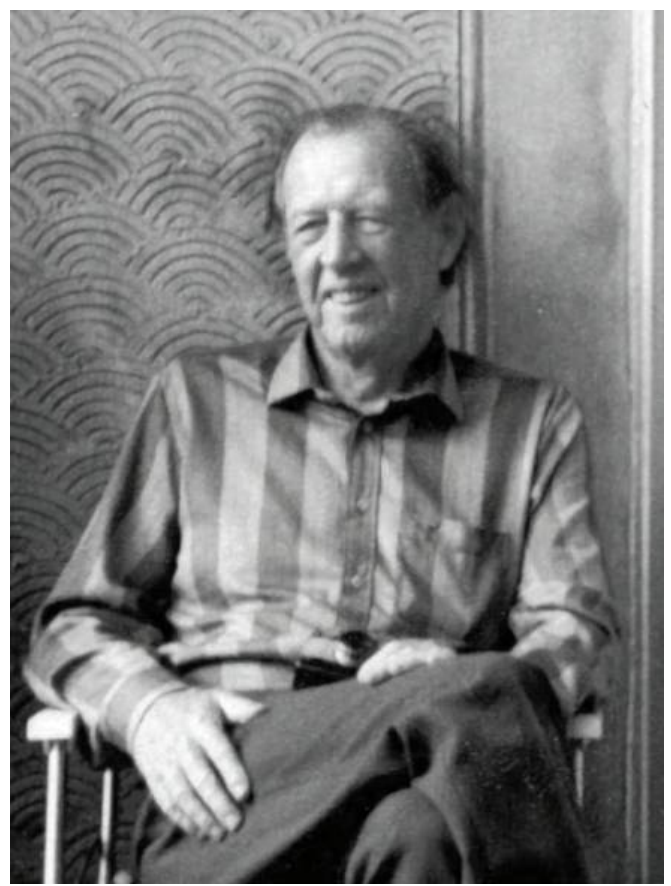

By GwydionM [Public domain], via Wikimedia Commons

Christian Fuchs:

The topic we want to start with is to talk a little bit about Raymond Williams and Cultural Materialism. So Nicholas, you knew Raymond Williams personally fairly well, and you worked also together with him. You even produced a documentary film about Raymond Williams; it was called Border Country and I found out it was broadcast on the $1^{\text {st }}$ of August 1970 on the BBC1 Pair of Eyes programme. The BBC described this film in the following way. It said, "Raymond Williams thinks higher education should be fitted to the demands of real life and believes many of Britain's rebellious students are, like him, inhabitants of a 'border country'."

Nicholas, you wrote yourself after Raymond Williams died that "he built single-handed the foundations for the distinctive tradition of British media and cultural studies," and that "he remained until his death by far its most distinguished and influential exponent (Garnham $1988,124)$. You also said that his stress "on the materiality of the cultural process is a necessary correction to both bourgeois idealism and its post-Althusserian Marxist variants" (Garnham 1979, 128).

I'm wondering if you can reflect back and report a little bit on your encounters with Raymond Williams, points of theoretical agreement and disagreement. And how do you assess what remains from his approach? Are there elements that remain very topical for the study of culture today?

\section{Nicholas Garnham:}

The important thing to stress about Raymond Williams's work is that he came out of a longer tradition of studying the relationship between cultural production, between what was then more generally called art, and wider social trends. He was shaped within the Cambridge University English Literature Faculty under the dominant influence of F.R. Leavis. Leavis argued, very much within the tradition that Williams himself later analysed as the Culture and Society tradition, that central to an understanding of the development of English literary production, to the quality of its texts and to its shifting relationship with a reading public was the shift from an agricultural, rural society to an urbanised industrial capitalist society. In Williams this analysis was then linked via an engagement with the work of precursors of Leavis within the Culture and Society tradition such as Ruskin and William Morris to a wider broadly socialist strand within British Historiography, particularly around the Communist Party 
Historian's Group - Christopher Hill, E.P. Thompson and Eric Hobsbawm. Here the central question was not the relation between cultural production narrowly defined and its social context and determinations, but the more general "State of England" debate - namely how to explain the dichotomy between Britain's advanced industrial capitalist development on the one hand and the absence of a fully fledged bourgeois revolution on the other hand with the peculiar state formation that had resulted. Within this general approach the question of working class culture became central as a way of understanding what was seen as the deeply reformist rather than revolutionary nature of British working class politics and political institutions. I think it is crucial to stress this grounding for Williams thinking, and for his always shifting and ambivalent relationship to Marxism in the light of later developments and debates within and around cultural studies, because this was an intensely British debate that could not be easily translated to other national political, social and cultural contexts.

So British cultural studies was formed via the Centre for Contemporary Cultural Studies (CCCS) in Birmingham within this general analytical and historiographical matrix with the question of the nature and dynamic of working class culture and its relation to political change as central. The next stage in development was the complex relationship between this tradition and European, particularly French, structuralist Marxism. The later divergences within and around cultural studies came out of the way you went in those controversies. Did you buy the baggage of the French Left bank theorists and the versions of Marxism that went with them or not? Broadly Raymond never did. He had interesting debates with some of them as we shall see, but was at the same time intensely wary. For instance he was always closest to Timpanaro's very heterodox take on linguistics and psychoanalysis than he was to the Lacanian post-structuralists and he never gave up on a faith in positivist, rationalist science.

That is, I think, the common ground that Raymond and I had with our interest in Bourdieu, who himself had a similarly antagonistic relationship to people who in his case had been fellow pupils or teachers at the École Normale. In France it was a very inbred, impacted debate between people who had been students together or who had been taught by different people. And there it was fought out in extremely personal terms. There is an extremely good book I would recommend by Tony Judt, who also studied at the École Normale, about that whole period and the thinkers who came out of it, and the complicated relationship that those thinkers had with Marxism in general and the French Communist Party in particular (Judt 1992).

So that's what I would still take from Raymond Williams: that it is a continuation of a tradition which remains in my view important, and its about the relationship between cultural production, widely defined, the social conditions which produce it and determine the forms of its distribution and reception. But within a specific, concrete historical, social and political context.

\section{Christian Fuchs:}

Raymond Williams is still interesting today because he was a cultural materialist. The dominant tendency in the culture and ideology today is critical discourse analysis that studies texts in order to identify ideologies in them and those ideologies' forms of argumentation. But it tends to neglect an analysis of the working conditions, under which ideologies are produced. Culture and ideology cannot exist without some people producing them in specific working conditions. Raymond Williams reminds us of this materiality of culture that always involves labour and work processes.

We can today find an idealist tendency in discussions about the cultural and creative industries. Already in the question "What is part of cultural and creative industries?", there is almost a pure focus on content and content producers. In the field that studies digital media and social media, there's a big focus on people producing content. Raymond Williams reminds us that the content cannot exist detached from the tools and from actual working and labour conditions (Fuchs 2014b, c, d; Fuchs and Sandoval 2014a). So if we browse on the Internet, somebody needs to have produced the content, but also someone needs to have produced the mobile phone or laptop that we use for accessing the Internet. Apple 
technologies are produced under very hard working conditions by assemblage workers in China (Sandoval 2013, Fuchs 2014b). The minerals come partly out of slave work in Africa (Fuchs 2014b). We should not forget these very material realities of the cultural content that we are confronted with.

\section{Pierre Bourdieu and the Sociology of Culture}

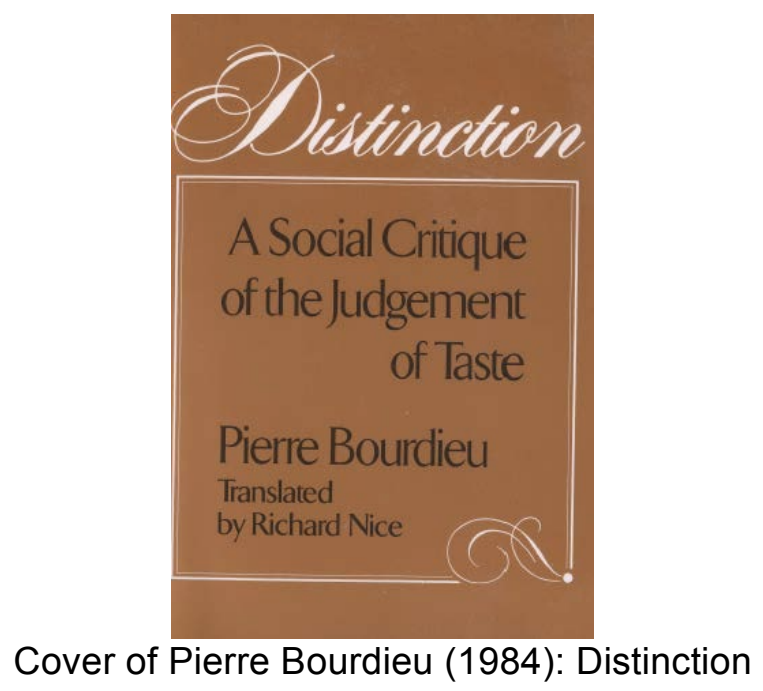

Christian Fuchs:

Let's talk about Pierre Bourdieu's Sociology of Culture that has been very important for Nicholas Garnham's work. In 1980, Media, Culture and Society (vol. 2, no. 3) published a special issue about Bourdieu and the sociology of culture. It featured an introduction written by you, Nicholas, together with Raymond Williams (Garnham and Williams 1980), two articles by Bourdieu (Bourdieu 1980a, 1980c) that later became part of his book Distinction (Bourdieu 1984), and an article that was published in French in 1979 and also translated for this journal issue (Bourdieu 1980b). So basically, the journal special issue was coming out in 1980. Distinction was not published in English before 1984. You made parts of Bourdieu's main work available some years prior to its publication in English. And in this interesting introduction that you wrote together with Raymond Williams, you describe Bourdieu's theory as "resolutely committed to a materialist theory of class struggle and of the position of symbolic struggle within that wider struggle", and you characterised it as "a positive and unpatronising evaluation of the cultural values and aspirations of the working class" (Garnham and Williams 1980, 85). When his book, Distinction, was finally translated into English (Bourdieu 1984), you did a review of it and you wrote that this book "is a book that changes the way [...] one thinks about one's own role as an intellectual" (Garnham 1986, 433). So it also makes us reflect about our roles in the intellectual world.

Today Distinction (Bourdieu 1984) is a classic of twentieth century social theory that most students of the social sciences get to read. What I'm wondering is what are the elements that you found, or have found and still find interesting in Bourdieu's work? And are there elements that you think remain especially important for understanding media and culture today?

\section{Nicholas Garnham:}

The reason I found Bourdieu interesting and important - and indeed similarly Raymond Williams did - was that firstly central to the debate and tradition out of which Williams and cultural studies came was a debate about what was loosely called "working-class culture" and whether modern capitalist life led to a deterioration of cultural standards - the cultural decline, vulgarisation theory - or not. Clearly Bourdieu's work is centrally about this issue. Secondly its important for its analysis of the differences between the cultures of various social groups or rather between the cultural formations determined by different social 
formations, and for separating that topological analysis from the questions of cultural value judgements. For Bourdieu cultural value judgements, especially aesthetic value judgements are purely and simply ideological. So Bourdieu's work is in part a critique of classical, particularly Kantian, aesthetics in favour of a sociological analysis of cultural valuation. I have always found this attractive and important. However I think he goes too far in relativising aesthetic judgement, but I will come back to that because I think it is one of the main problems of Bourdieu's work.

The second reason for an interest in Bourdieu was that he had written a very important study of photography as a popular art form, both in its production and reception (Bourdieu et al 1996). And he had also written a study of museums going from the same perspective (Bourdieu, Darbel and Schnapper 1997). So he was interested in photography as a precursor of what we would now call social media, because he saw photography as a form of social and cultural expression, which had escaped from the received, class bound categories of cultural production. It was something that was used and consumed by everybody and Bourdieu was interested in what kinds of photos people liked to take and look at and how they evaluated them and why. So it was an extremely good test case for the impact of a new technical medium and the different forms of cultural production and reception that resulted within different social groups.

The third reason I found Bourdieu interesting - and still find him interesting and important - was because he was positioned against the debate on ideology, which was very, very central at that time. Ideology was seen as something which was propagated by a particular social group, or class, in their interest and, so to speak, took people, ensnared people, captured people, gave them a false consciousness; however you want to put it, it had some bad effect on people because they have absorbed it. And of course the biggest bad effect was that it made the proletariat non-revolutionary. Bourdieu took a very, very different view of what was called ideology. He stressed, and I still think this is extremely important sociologically, the absolutely central role that habit plays in human social life; that we simply couldn't get through the day unless we carried out a whole range of completely automatic routines. You cannot think about everything you do. And to that extent, if you want to call that ideology, then we are governed by ideologies - and necessarily so. The same is true of stereotyping. Stereotyping is seen as a totally bad thing, especially racial or gender stereotyping. But the fact is we all stereotype and we couldn't operate as human beings unless we stereotyped. In this context I have been greatly influenced by Norbert Elias in thinking about modernity, social structure and the role of the media. For Elias the social structures and modes of behaviour characteristic of modernity have been above all developed as a way of dealing with constant encounters with people we do not know - the anonymous other. The ways we deal with the anonymous other, and of course the market is one such institutional mechanism, remains central.

So those are the reasons I think Bourdieu was, and indeed remains, important. I parted company with him over two issues. Firstly I thought that the way he constructed his theory led to a kind of cultural Weberian iron cage out of which there was no escape. We are all trapped by these social positions and the cultures produced by them. It seems to me that from this position it is difficult to account for medium term cultural, social or political change. Indeed the theoretical analysis is itself derived from anthropology, i.e. the study of essentially unchanging societies. Here I should note that such anthropological theories have themselves been critiqued within anthropology as exaggerating the static state of the societies they study. Furthermore you certainly cannot explain any forms of socially oppositional activity, except as delusional, i.e. yet another form of adaptation to the status quo.

My second difference with Bourdieu concerned his extreme rejection of aesthetic evaluation as anything other than and always the ideological expression of a class position. That is to say I think you can explain with his categories how a particular cultural formation comes about, how certain artefacts are produced rather than others and by whom, down to a quite detailed level. And you can explain up to a point why some people like some things and dislike or reject others. But this still leaves an important unexplained residue. You cannot explain why people participate in cultural or artistic activity, whether production or 
consumption, in the first place. We still need to explain why people get pleasure out of performing or listening to music, writing or reading literary texts. And also why, within each subcategory of cultural production and reception, even if that category is class determined, there is, at least over the medium term, some agreement among consumers that some people do it, whatever it is, better than others. None of this can be explained within Bourdieu's theory and I think this is a major problem.

What I find interesting is that Bourdieu's later work illustrates this problem very starkly. He spent his last years largely critiquing contemporary French media in a way quite at odds with his own theory for failing to maintain high cultural standards because of commercialism and Americanisation. A sad collapse to the level of Dwight MacDonald and then old prophets of vulgarising doom.

\section{Christian Fuchs:}

The two points of criticism that you mentioned are interesting, that on one hand Bourdieu did not give enough attention to resistance and opposition in society; and on the other hand, the foundational dimension of creativity and aesthetics in society. If you look at French social theory today, the two big figures are Bruno Latour and Luc Boltanski. Boltanski worked with Bourdieu, but then their ways parted. There's an interesting debate between Luc Boltanski , who we could say is the new Bourdieu of French social theory, on the one hand and Axel Honneth, who we could say is the new Habermas in German critical theory, on the other hand (Boltanski and Honneth 2009). Boltanski says he turned against Bourdieu at a certain point of time. And one of the reasons for Boltanski was exactly that he felt that Bourdieu's theory was too much an iron cage. Another issues for him was that he felt Bourdieu did not see that when there are capital structures that result in inequality, the question arises where the starting point for resistance is. Boltanski sees such resistance in everyday opposition and argues for a pragmatic sociology of critique. He argues for observing how people who live in structures, are confronted with structures of inequality, how they react in their everyday lives to it.

Whereas Boltanski takes a more immanent, subjective and empirical position that he terms sociology of critique, Honneth argues in line with the Frankfurt School for a more transcendental, objective and moral philosophical approach that he terms critical sociology. Boltanski was invited by Honneth to give the 2008 Adorno lectures in Frankfurt. Boltanski (2011) in these lectures distinguished his approach of a pragmatic sociology of critique from critical sociology. In France, especially Pierre Bourdieu would have taken the latter approach. But the Marxist tradition can in his view in general be described as being closely to critical sociology that tries to unmask domination, exploitation and oppression as well as ideologies justifying these phenomena (Boltanski 2011, 6). Boltanski describes the pragmatic sociology of critique as "rigorous empirical sociology" (23) that does not assume an asymmetry between the sociologist and ordinary people and aims to describe the reality and experiences of the oppressed. It would make use "of the point of view of the actors [...], their ordinary sense of justice, to expose the discrepancy between the social world as it is and as it should be in order to satisfy people's moral expectations" (30). Boltanski criticises that critical sociology in his view has an "overarching character" and a "distance at which it holds itself from the critical capacities developed by actors in the situations of everyday life" (43). The pragmatic sociology of critique would fully acknowledge "actors' critical capacities and the creativity with which they engage in interpretation and action en situation" (43) for "denunciations of injustice" (37).

In the conversation with Honneth (Boltanski and Honneth 2009), Boltanski points out that his approach is not to denounce Marxism, as Bruno Latour does, but to take it into a new direction. Just like Boltanski says that in his view Bourdieu's approach saw domination everywhere and was lacking a sense for the immanent contradictions of society, Honneth says that Habermas, whom he considers as his main influence, saw Horkheimer and Adorno's approach as a total critique where everything is domination. The conversation between Boltanski and Honneth (2009) makes clear that Boltanski takes an explicitly empirically grounded approach, whereas Honneth has developed a moral philosophy. 
Honneth argues that the reality of actors to use critical capacities would be unequally distributed so that critical sociology would have to analyse the limits that social conditions pose for humans (105f). Boltanski says that his approach is not to use moral philosophy and normative critique, but to assume that there are immanent contradictions in reality and that there is always something in the world that "goes beyond reality" (107). Boltanski argues that ideologies would be something that only those in power needed, whereas everyday people would make many experiences that go beyond ideology (108).

Boltanski (2011) terms normative critical theory "meta-critical theory" (8) or metacritique (6) because it would need an exteriority in order to judge what is good and bad. He argues for a purely immanent critique that is grounded in the empirical observation of how humans experience suffering in society and thereby criticize society. Boltanski's pragmatical sociology of critique is purely immanent. Honneth in contrast is more sceptical and does not see critical capacities developing with necessity in society. He stresses the need for a normative critique and a critical theory as immanent transcendence.

Honneth (2007, 57-69) distinguishes between a constructive, transcendental critique; a reconstructive, immanent critique; and a Foucauldian genealogical critique. Critical theory would combine all three forms. In the debate with Fraser, he characterises this combination as immanent transcendence. Transcendence "must be attached to a form of practice or experience which is on the one hand indispensable for social reproduction, and on the other hand - owing to its normative surplus - points beyond all given form of social organization. [...] 'transcendence' should be a property of 'immanence' itself, so that the facticity of social relations always contains a dimension of transcending claims" (Fraser and Honneth 2003, 244). Fraser sees the immanent element of contemporary society that can transcend it in social movements that engage in political struggles (Fraser and Honneth 2003, 205), whereas Honneth is very critical of new social movements (Fraser and Honneth 2003, 114125), considers them as rather affirmative, and sees immanent transcendence in an objective morality that should be legally implemented in the form of laws (see Fuchs 2011, chapter 2, for a detailed discussion of immanence and transcendence in Critical Theory).

The other point you were making is that people seem to have this desire for creating something that is an aesthetic creative value. I think neither Boltanski nor Honneth can really answer this question. So there might be a lack of attention to these kinds of questions in critical theories in general.

\section{Nicholas Garnham:}

Well I don't know about lack of attention, but I think it remains a central problem. It gets back to the whole question of whether post-modern theories are entirely relativist; can you make value judgements about anything including in this case cultural objects or practices.

In my view there are two things to be said about that. One that it seems to be anthropologically agreed that all human cultures produce these things or participate in these practices. Second there is good deal of evidence that while content may be codified in different ways in different cultures - for instance different systems of musical harmony there seems also to be a universal response to certain basic aesthetic categories such as form or movement. So for instance responses to architectural space are cross-cultural even if the cultural use of the building in question - church, mosque, temple - may differ. And I think this has $t$ be taken into account in any analysis of culture. I don't have any particular answer to that problem but you cannot just wish it away.

\section{Christian Fuchs:}

I think it goes even further. Aesthetics is embedded into the whole realm of knowledge production and communication. This goes back to a very foundational question in critical theory and social theory - the relationship of the economy and culture, of base and superstructure. Even Habermas and a lot of other critical social theorists always separated these two realms. On the one hand they say there's the world of work, and on the other hand there's aesthetics, communication and culture. Habermas $(1968,2004)$ goes back to Hegel's Jena system of philosophy (Hegel 1803/1804, 1805/1806), from where he takes the 
distinction between work and interaction. Throughout his whole work, even in the theory of communicative action (Habermas 1984), you can see this dualism. On the one hand there's the instrumental logic of the economic world, and on the other hand the non-instrumental reason of communication in the cultural realm. I felt always that he keeps these two realms too separate.

Hegel (1803/1804) argues that human reason produces the spirit that expresses itself as memory and language and is practically expressed in the form of work (197). So the connection of work and language is for Hegel that they are both utterances of the human spirit. Hegel says that the spirit of a people is an "active substance" (224). It would create works (224). One of the works of a people would be language (226), another one work and property (227). Hegel stresses that both language and work do have a general character: they connect single individuals $(227,229)$. Language would be the existence of consciousness $(200,208)$. Hegel grounds foundations of semiotics by arguing that in language one finds symbols that signifies something outside of it (201).

Hegel $(1803 / 1804)$ says that work is a specific form of the spirit - an expression of human drives (210f). Tools would be means of humans to obtain the end of satisfying desires. Labour would be the middle of desire and a resulting object (211). In the practical work process, the tool would be the middle of the subject and the object (211). The satisfaction of needs would be a "general dependence of all on all" (229). The machine would be a tool that humans use for minimizing the value of goods: "the more machines mediate work, the less value it has" (228). "But in the same proportion as the produced quantity increases, the value of labour decreases" (230). The result would be dead labour, "machine labour" (230) and the dullness of factory labour (230). Value would be the "identity in the thing" (Hegel 1805/1806, 207f). "The general is the value" (Hegel 1805/1806, 208). Exchange would be the movement of the thing (Hegel 1805/1806, 208).

Hegel grounded a phenomenology of work and communication and pointed out that both have in common that they are general qualities and products of human social activity. Although communication and work have for Hegel in common that they are social and general products of human activity, they are for him two separate domains of society. Communication and culture are however also specific results of information work. And communication is the crucial social feature of work organisation. One could go one step further and say that communication is an essential human use-value and therefore a form of work. So communication is work and work always involves communication.

Habermas (1968) based on Hegel's Jena system argues that consciousness and the mind would be media of communication. The difference between work and interaction would be that the first is a form of strategic action and the second oriented on understanding. Strategic action would make decisions without trying to reach understanding with others (Habermas $1968,22)$. Both work and interaction would constitute the external nature of humans, their relational being. In work, there is a relation to nature organized by tools. In communication, there is a relation to other humans organized by language and its symbols. Work and interaction could not be reduced to each other (Habermas 1968, 3), but they would be dialectically connected: "But now also instrumental action, as soon as it enters the category of the actual spirit in the form of societal work, is embedded into a network of interactions and is therefore itself dependent on the communicative boundary conditions of every possible cooperation" (Habermas 1968, 32, translation from German).

In the Theory of Communicative Action, Habermas $(1984,1987)$ formalised the earlier drawn distinction between work and interaction in his own theory in the form of a distinction between instrumental-strategic rationality and communicative rationality. He understands rationality as "problem-solving action" (Habermas 1984, 12) and introduces a typology of action, in which he differentiates action types based on action situations (non-social or social) and action orientation (oriented to success, oriented to reaching understanding). This results in the distinction between instrumental action, strategic action and communicative action. Instrumental and strategic action are oriented on success and driven by "egocentric calculations of success" (Habermas 1984, 286). Instrumental action means that an actor identifies and uses means in order to achieve ends and maximize his/her benefits 
(Habermas 1984, 285, 85). Strategic action is instrumental action in a social situation with rational opponents so that the task is to beat the opponent or be more successful than him/her (Habermas 1984, 285).

In contrast, communicative action the action situation is social and the orientation is "reaching understanding" (Habermas 1984, 286). "In communicative action participants are not primarily oriented to their own individual successes; they pursue their individual goals under the condition that they can harmonize their plans of action on the basic of common situation definitions" (Habermas 1984, 286). "The actors seek to reach an understanding about the action situation and their plans of action in order to coordinate their actions by way of agreement. The central concept of interpretation refers in the first instance to negotiating definitions of the situation which admit of consensus. [...] language is given a prominent place in this model" (Habermas 1984, 86). Reaching understanding in communicative action would require the three validity claims of truth, rightness and truthfulness (Habermas 1984, 99). Habermas' distinction between instrumental and communicative action is reflected in his distinction between systems and the lifeword. He locates work/labour in the interchange relationship between the economic system and the private sphere that is part of the lifeworld (Habermas 1987, 320). This relationship would be a determined by the systemic steering media of money and power (exchange of money in the form of the wage for the control of labour power). Habermas $(1976,151)$ argues that work and language were necessary preconditions for the emergence of humans and society. Reconstructing Historical Materialism would require separating "the level of communicative action from the level of instrumental and strategic actions that are united in societal cooperation" (Habermas 1976, 160 , translation from German to English). Historical progress would only be possible by developing the forms of social integration and the productive forces (Habermas 1976, 194).

Habermas consistently used the distinction between communication and work that he took from Hegel's Jena philosophy for creating a theory of modern society. Communication and work represent for him two different logics of society, an emancipatory and an instrumental one. He is critical of money and power's colonisation of lifeworld communication (Habermas 1987) and so stresses the importance of defending communication against instrumental logic. Habermas' political imperative is definitely laudable because it helps is to stress that there is a society beyond capitalism and that a true society is not steered by capital and domination. But the question is if it is feasible to dualistically separate communication and work - an approach that Habermas characterizes as media dualism (Habermas 1987, 281).

There are several theoretical limits of Habermas' work/communication dualism:

- In a general sense, we can say that reaching communicative understanding and any form of communication is a form of instrumental action: the means of language is used for achieving the goal of relating oneself to other humans and reaching a joint understanding of the world.

- Communication in modern society is not an immune sphere: Ideologies are forms of communication and language that are highly instrumental. Ideologies instrumentalize language and meanings for justifying exploitation and domination. Communication thereby becomes an instrument of domination. Within communication studies, a specific field called strategic communication has developed. It studies how communication can be used for influencing and persuading specific audiences of particular purposes, especially in marketing and politics (see Hülsmann and Pfeffermann 2011, Paul 2011). Strategic communication is just another term for propaganda that serves capitalist and bureaucratic purposes. So communication is not immune from the logic of instrumentalizing humans and speech for domination, but can serve quite different purposes.

- Work not only serves strategic-instrumental purposes, but can be quite altruistic and motivated by helping others and fostering the common good that benefits all. Marx was convinced that an entire society can be built on the logic of common goods. Limiting the notion of work to strategic-instrumental action deprives theory of a vocabulary for conceptualizing social activities that produce use-values in a society based on solidarity, common goods and voluntary work.

One can go back to Raymond Williams' cultural materialism and based on it argue that we 
must treat the production of beauty, the production of knowledge, from a very fundamental anthropological point of view, also as a form of work; a specific form of work, but also one that in the end produces use-values that satisfy human needs. Because in addition to basic survival conditions like eating, sleeping and so on, there seems to be also a need for beauty, for communication, for social interaction and for culture.

In Marxism and Literature, Raymond Williams questions the Marxism's historical tendency to see culture as "dependent, secondary, 'superstructural': a realm of 'mere' ideas, beliefs, arts, customs, determined by the basic material history" (Williams 1977, 19). He discusses various Marxist concepts that Marxist theories have used for discussing the relationship of the economy and culture: determination, reflection, reproduction, mediation, homology. These approaches would all assume a relationship between the economy and culture with a varying degree of causal determination or mutual causality. But all of them would share the assumption of "the separation of 'culture' from material social life" (Williams 1977, 19) that Williams $(1977,59)$ considers to be "idealist". The problem of these approaches would be that they are not "materialist enough" (Williams 1977, 92).

Williams $(1977,139)$ concludes that Cultural Materialism needs to see "the complex unity of the elements" required for the existence of culture: ideas, institutions, formations, distribution, technology, audiences, forms of communication and interpretation, worldviews (138f).

He formulates as an important postulate of Cultural Materialism that "[c]ultural work and activity are not [...] a superstructure" (Williams 1977, 111) because people would use physical resources for leisure, entertainment and art. Combining Williams' assumptions that cultural work is material and economic and that the physical and ideational activities underlying the existence of culture are interconnected means that culture is a totality that connects all physical and ideational production processes that are connected and required for the existence of culture.

If one thinks dialectically, then a concept of culture as material and necessarily economic and at the same time distinct from the economy is feasible: culture and politics are dialectical sublations (Aufhebung) of the economy. Sublation means in Hegelian philosophy that a system or phenomenon is preserved, eliminated and lifted up. Culture is not the same as the economy, it is more than the sum of various acts of labour, it has emergent qualities - it communicates meanings in society - that cannot be found in the economy alone. But at the same time, the economy is preserved in culture: culture is not independent from labour, production and physicality, but requires and incorporates all of them.

\section{Nicholas Garnham:}

I think that is two different issues. It seems to me it is true for Habermas there is that bifurcation, but it is based on a preceding common base. That is to say I do think he takes from Hegel the notion that all human activity is interactive, but maintains - in my view rightly - the Kantian distinction between interaction with the material world and interaction with other humans in the social world. They both could be defined as work if that is how you want to define work, but they do have once that division is made, distinct dynamics and they tend to build around themselves distinct value systems. So I don't have any problem about separating them out and clearly recognising this difference.

Now that is a different question from the question of communication or cultural work, which also involves material work. That is more what I think Raymond Williams is addressing, and I think it's a very important stress. For obvious reasons idealism retains a very strong hold in cultural analysis - indeed much of the argument between cultural studies and political economy to which we will come on stems from the more than residual idealism in structuralism and post structuralism and thus within those current within cultural studies-. You know too many people seem to think that there are texts or images and somehow they are there in the world, that they are sort of plucked out of someone's head somewhere and placed in the world and then someone reads them or whatever, does whatever they do with them. Whereas even the most basic writing, the most basic text, involves a struggle with an object language that cannot be just put in any form, as well of course as the deployment of 
acquired skills and knowledge, forms of cultural capital that are not just there for the asking. So that form of work is central to all forms of communication and cultural practices. I think that is a different issue as to whether it is all work in the same sense.

\section{Christian Fuchs:}

It seems to me that two dialectics are even involved here. On the one hand, if work just means the basic production of use-values that satisfy human needs, then we can split them up into use-values that are symbolic and use values-that are physical. And then the symbolic form is a peculiar use values. It is peculiar because of all the specific characteristics of information as a public good that media economics describes: information is not used up during consumption, can easily be shared, be quickly and cheaply copied and transported, can be consumed simultaneously by many people, has large initial production costs, but low to zero reproduction costs, can often only be sold when it becomes a "hit" as part of a broader portfolio, can face the problem of Baumol's disease of how to increase productivity, and has uncertain demand which causes high risks. This seems to be one issue, whereas on the other hand when we just look into this realm of the production of information, then it seems itself to have a very material foundation. So when you write a letter, someone needs to have produced the pen and someone needs to have produced the paper.

Marx $(1857 / 58,305$; see also Williams 1977, 93) in the Grundrisse has the example of the piano player so that when we produce music with the piano of course you need the composer and you need the player, who needs an artistic skill; but at the same time, we need the piano-maker who makes the piano. If the economy and culture are seen as two separate realms, then building the piano is work and part of the economy and playing it is not work, but culture. Marx leaves however no doubt that playing the piano produces a use-value that satisfies human ears and is therefore a form of work. As a consequence, the production of music must just like the production of the piano be an economic activity. Williams (1977, 94) stresses that cultural materialism means to see the material character of art, ideas, aesthetics and ideology and that when considering piano making and piano playing it is important to discover and describe "relations between all these practices" and to not assume "that only some of them are material".

Besides the piano maker and the piano player there is also the composer of music. All three works are needed and necessarily related in order to guarantee the existence of piano music. There is an analogy between piano music and digital work. Just like we find piano makers, music composers and piano players in the music industry, we find work involved in hardware production (makers), content and software production (composers) and productive users (prosumers, players, play labour) in the world of digital work. So also in the realm of digital work (Fuchs 2014b), we have to emphasize that practices are "from the beginning social and material" (Williams 1989, 206).

\section{Political Economy vs. Cultural Studies}

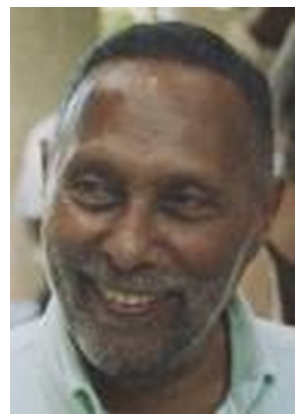

Stuart Hall, source:

http://upload.wikimedia.org/wikipedia/commons/8/8a/Hall_Stuart.jpg?uselang=en-gb

(Free Art Licence) 


\section{Christian Fuchs:}

Let's discuss a related topic in cultural theory: the relationship between cultural studies and political economy. You were in the 1990s, involved in a foundational debate of media and communication studies with Lawrence Grossberg. It was published in the journal Critical Studies in Mass Communication and focused on the relationship between political economy and cultural studies when studying media and communication (Garnham 1995a, b, Grossberg 1995). This was a powerfully eloquent discussion. Oscar Gandy, who was the journal's editor at this point of time, wrote in the introduction that Angela McRobbie "was so outraged and insulted by Garnham's initial draft that she simply could not respond" (Gandy 1995, 60). And Lawrence Grossberg, in his contribution, argued that Nicholas Garnham's "version of political economy is too reductionist and reflectionist for cultural studies" (Grossberg 1995, 78) and that therefore he "must decline the invitation to reconcile" because cultural studies and political economy "don't need a divorce because [they] were never married" (Grossberg 1995, 80).

You argued in the initial paper that Cultural Studies "came out of a set of assumptions about political economy", as evidenced by the works of people such as Raymond Williams and Edward P. Thompson, but that it later developed "a profound misunderstanding of political economy" and that the "project of cultural studies can only be successfully pursued if the bridge with political economy is rebuilt" (Garnham 1995a, 62). A major issue in this debate was the relationship of class and identity: "How is it possible to study multi-culturalism or diasporic culture without studying the flows of labor migration and their determinants that have largely created these cultures? [...] How is it possible to study advertising or shopping, let alone celebrate their liberating potential, without studying processes of manufacturing, retailing and marketing that make those cultural practices possible" (Garnham 1995a, 71).

Can you reflect back a little bit on this foundational debate and tell us more about how this colloquy in Critical Studies in Mass Communication came about? And now with hindsight of almost twenty years, what do you consider is its main contents, its main consequences, and what can we make of this debate today?

\section{Nicholas Garnham:}

I have no memory of how that came about. All I can say is a continuation of what I said about Raymond Williams; that this debate was always embedded in the development of British cultural studies. First there was a debate between the more materialist views of culture and more idealist views of culture. And then there was a debate between the Marxists and the non-Marxists on the other - to put the matter extremely crudely.

I certainly saw the debate as the continuation of something that had been going on for a long time. There was for instance the ongoing debate between those who bought into the general turn towards grand theory, French post structuralism and Marxism, psychoanalysis and the wider so-called "cultural turn" for whom engrained British empiricism as they saw it was the problem on the one hand and those who took a more sociologically grounded approach - within which I would include some notion of economy, political economy, historical materialism. Neither the various positions themselves nor the differences between them were in anyway simple. Nor should they be simplified into a Manichean debate between cultural studies and political economy. But unfortunately that is what has tended to happen. As usual in such cases enlightenment has been the casualty. But at the time a great deal of emotional energy was invested in various theoretical positions. Looking back now it seems bizarre that anyone should have cared whether Althussser was right or wrong. But at the time they did - desperately.

But it has to be stressed that the colloquium was in the relatively early days of the development of post-modernism or post-structuralism that had such an impact on British and American cultural studies. I thought at the time, and still think, that that move was a mistake - but I and others who thought like me lost the argument. Well, we didn't lose the argument; the historical tide was against us and with some tides that is just the way things go. I think from a Bourdieuian position there are many ways in which one can explain this sociologically. That is why - you mentioned my review of Distinction (Garnham 1986) - you can learn a lot 
from Bourdieu about your own positions and the positions of those with whom you argue where they come from etc - and at certain times that's just the way things are. There is no point in getting agitated about it.

The problem is that I think - and I thought then - that Grossberg and others misunderstood what I was saying - which may be because I didn't put it very well, but more importantly misunderstood what $I$ at least thought political economy was about, which certainly wasn't reductionist. It was admitting what we have just been talking about, that these are material processes, that, in the world in which we live, for better or worse, many of these material processes are organised in ways which we can analyse and which you can describe as capitalism or advanced industrialism. There are various possible ways of characterising these material processes, but they are organised in specific ways and we can say something about their dynamics. You may then want to go on and make social and moral judgements about the outcomes - that is a separate issue. But I think it is just stupid to deny they exist. So that is one problem.

The other problem - and I still think this is the case - was that I thought the cultural studies people - and this does back a long way in the debate - were exaggerating the effects of what is narrowly called cultural practice on life in general and its development. For all the talk of an information society and so on and so forth, if you look at current debates about where our society is going, the important developments are not cultural, they are not the development of social media or anything; I mean that is the frith on the surface. The things that underlie it are things like shifting demographics and levels of productivity growth in the economy. If you look at the global economy, for all the talk about culture and information, what are the things that most concern people? Energy production, access to clean water. The big fortunes are being made not in high-tech or the digital economy but in mining. The biggest problem facing the global economy is physical transport infrastructure a shortage of port capacity and railway lines - moving things about.

So I think there were two parts to this argument. As it happens I think I was right on both of them. But I didn't win the argument. And cultural studies talked itself into irrelevancy as a result. Sad, but there it is.

\section{Christian Fuchs:}

If you look at cultural studies now, there's a rediscovery of the importance of the economy (for a detailed discussion see Fuchs 2014b, chapter 3) in books such as Lawrence Grossberg's Cultural Studies in the Future Tense (Grossberg 2010) or John Hartley's (2012) Digital Futures for Cultural and Media Studies and others. In the situation of global capitalist crisis that we are now in, it's very hard to deny that for any form of media and culture, advertising and so on, capitalism and the crisis of capitalism form important contexts. In the end you've won the argument because now they are finally acknowledging that if you're studying culture you cannot do it without connecting cultural analysis to economics. So I think the argument that you can now often find in Cultural Studies is basically, "Take economics seriously and engage with economic theory". But then my response to it is, "Yes, I agree, but isn't this what the political economy approach has always been doing?". So it looks like a lot of cultural studies people have turned into political economists now. It looks to me that you have not lost the argument but that in the end, in the context of the crisis, you have won it.

I looked up the passages where Grossberg (2010) in his book Cultural Studies in the Future Tense, specifically refers to you. But then, of course, he says it should be a different kind of economics; so he says that most materialist economic theories nowadays within the political economy of communication approach and outside of it practice a crude form of reductionism (Grossberg, 2010). Grossberg says specifically that cultural studies should engage with economics in a way "which would not reproduce the reductionism of many forms of political economy" (Grossberg 2010,105). Looking back on the debate between cultural studies and Marxist/critical political economy of the Media, he says that Cultural Studies opposes "economic and class reductionism" and refuses "to believe that the economy could define the bottom line of every account of social realities" (Grossberg 2010, 105). He says we need to do the analysis of culture differently today, but the problem is that he in the final 
instance rejects Marx's theory.

The late Stuart Hall said in an interview in 2012 that cultural studies should embrace and engage with Marx's theory, but that the unfortunate reality is that it does not do so. "In its attempt to move away from economic reductionism, it [Cultural Studies] forgot that there was an economy at all. It is not in a wonderful position [...] They would [Cultural Studies scholars] have to go back and ask themselves: [...] What is the role of the economic in the reproduction of material and symbolic life? They'd have to ask themselves economic questions. [...] It's more like a return to what Cultural Studies should have been about and was in the early stages. It sort of lost its way very much. [...] I'm sounding like the headmaster I never wanted to be"2. "It is not that Marxism is not around. [...] A Marxist tradition of critical thinking is absent [...] in Cultural Studies [...] And that's a real weakness. That's one of the reasons why l'd say we're not in a very good position. [...] I want to reengage the same kind of issues. This is what Cultural Studies was in the beginning" ${ }^{3}$. Grossberg ought to better listen to Hall and give up the "anti-Marxism" because it hits at a "wrong target" (Miller 2011, 322).

There are also political economists like Bob Jessop making advances towards cultural studies. Jessop wrote a couple of years ago an article about foundations of what he terms cultural political economy. The article was inspired by Grossberg's work (Jessop and Oosterlynck 2008). In their new book about cultural political economy, Sum and Jessop (2013) take this issue up again. Grossberg (2010) responded to Jessop and rejects political economists who now open up to deal with culture and the media. Grossberg (2010) says he is hesitant to sign up with Jessop because "the project is entirely macro-economic" (119) and the "category of the economic itself still remains inviolable, presupposed, and perhaps even transcendent" (120). I together with colleagues invited Bob Jessop as a keynote speaker to the European Sociological Association's conference this past August, where he spoke about his cultural political economy approach. The other person who was a keynote speaker in the same panel was Graham Murdock ${ }^{4}$. But the interesting thing was that Bob Jessop had heard a lot about Lawrence Grossberg; but he'd never heard about Graham Murdock and the British tradition of political economy of communication. So I felt Grossberg might be the wrong friend for Jessop because there is since the 1970s a long tradition of political economy of media and culture that is more connected to the approach that Jessop wants to take now than the kind of cultural studies that Grossberg practices.

\section{Nicholas Garnham:}

I don't know what sort of economics Larry Grossberg is now suggesting, but I would suggest tentatively to him and others like him that you cannot suddenly say, 'l'm going to become a political economist'. They need to read some economics. Otherwise they may just be reinventing the wheel trying to understand the dynamics of modern societies, in which a large part of activities are organised in certain specific ways which have come to be known as capitalism, is not easy. Many greater minds than either Grossberg's or mine have failed at the task. That is the other side of it. There is some notion that 'now we have got to think about the economy'. Most of the people I read haven't even begun to look at the real problems. They come back to, they return to Marxism and to some misunderstood and, in my view, insufficiently critical version of Marxism. The problem is that there is a real danger, and it is to do with the nature of modern academia and the knowledge production world, of simply latching on to a new fad. 'Oh that approach didn't work so what's the next thing? Oh we'll fix it with a bit of political economy'. It doesn't work like that I am afraid.

\footnotetext{
${ }^{2}$ Stuart Hall interviewed by Sut Jhally, London, August 30, 2012. http://vimeo.com/53879491 ${ }^{3}$ lbid.

${ }^{4}$ Editorial note (Christian Fuchs): European Sociological Association: 2013 Conference "Crisis, Critique, and Change": Semi-Plenary 02SPS - Critical Political Economy of Media and Communications in Times of Capitalist Crisis. Keynote talk by Bob Jessop: The North Atlantic Financial Crisis, Crisis Construals, Crisis Management, and Crisis-Displacement. Keynote talk by Graham Murdock: Crisis and Critique: Reconstructing Political Economy. August 29, 2013. Turin, Italy.
} 


\section{Information Society as Theory or Ideology?}

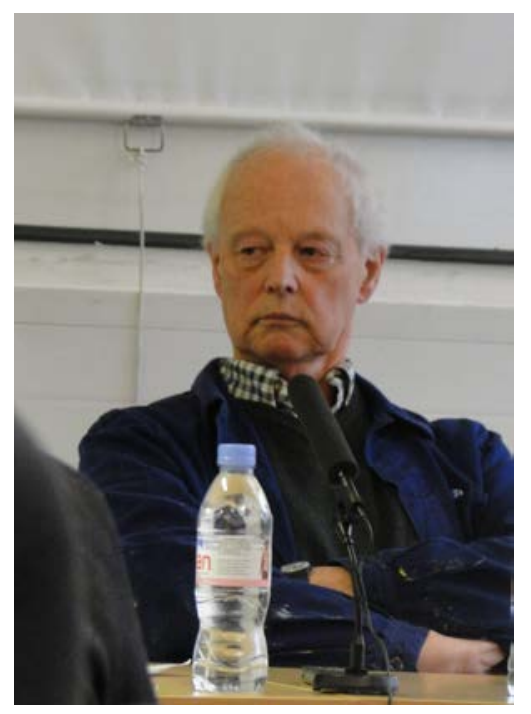

\section{Christian Fuchs:}

A major topic in social theory is the concept of the information society. So, at least since the early 1960s when Fritz Machlup published his famous book The Production and Distribution of Knowledge in the United States (1962), there have been huge debates about the role of knowledge and information technology in the economy and society. In the 1970 s this resulted in Daniel Bell (1974) and others' claims that we live in a post-industrial or information society. In the 1990s, with the rise of the Internet, the debate more developed in such a way that people, and especially Manuel Castells $(1996,1997,1998)$, were talking about the rise of a network society, but based on Daniel Bell's approach. In the ' 90 s and also later on, you were also involved in intervening into this debate (for example: Garnham 1998, 2000b, 2004a,2005, 2008), especially in the context of a critique of Castells' work. Back then you were writing in a review of Castells that the concepts of the information society and network society form "the dominant ideology of the current historical period" (Garnham 1998, 118) that has "no objective co-relative in the real world" (Garnham 2000b, 151). As "an ideological mantra", the concept of the information society "merely and dangerously distracts - as is often intended - from the real issues" (Garnham 2000b, 151).

I found interesting in your chapter in the Handbook of Political Economy of Communication called "Political Communication Revisited" that you argue for using the term "the political economy of information" and the term "political economy of information society". And you mention to a certain extent there is a need for an "important and [...] necessary shift in perspective (Garnham 2011, 52). So I'm wondering, how can we make sense of information society theory today, its basic assumptions about the role of information in society, and how do you assess these claims today?

\section{Nicholas Garnham:}

In terms of the critique of Castells what I was concerned with was the use of the term "information Society" to explain, to describe and then draw some conclusions from a supposedly stage theory of capitalist development, in which we have moved from an industrial economy to some kind of economy called an information society. That approach I rejected for a number of reasons. This was a different argument to that which I made in the Handbook, where I was saying that it is better to think about the media, as they have been traditionally defined, within a wider context of development, because clearly you get a crossover from a media system composed of printed newspapers delivered by road and train and radio and television channels broadcast over the air ways to a world in which they are 
increasingly intertwined with telecommunications and digital networks and the Web and so on. And therefore you need increasingly to see them as a sub-sector of those wider developments. So I was making two rather different distinctions.

I still stand by my critique of Castells. But I think that the crucial point, and actually the issue that the originators of the theory - Daniel Bell, Machlup and so on - were really concerned with was the implications of the shift to what was loosely called a service economy. There are various ways of describing this shift, but the crucial point was that increasingly that work did not involve directly the production and distribution of material things. A lot of work was in fact the administration of physical production and distribution, but that is a sub issue within the more general discussion. Now one of the key questions relating to this shift was from the beginning that of productivity.

This may sound like a very boring, arcane discussion to those used to the intellectual fireworks of cultural studies. But people here may have read in the last week of a study from either the OECD or the IMF showing that post the crisis over the last few years, surprisingly, - it is not what would have been expected in the situation - levels of productivity growth in the world economy have fallen. Certainly that has been true in Britain. In the post crisis period unemployment has not risen as much as was expected, but the other side of that coin has been a fall in productivity.

Now we are getting a long way from communication and cultural studies here - sorry folks. But the question of productivity is absolutely central to understanding political economy. The key to the move into what became capitalism, and therefore the whole modern world, was the decisive shift made first in Britain from an almost static, very low productivity agricultural economy within which most people barely survived and the population merely reproduced itself to a world of sustained and expanding productivity and growing populations. This remains the driving force. We live in the world we do because people can produce more stuff in a shorter time, and therefore there is a lot more to go round for all of us; some certainly get more than others, but nonetheless in general for all of us. Now productivity grew over a long historical period in the capitalist industrial economies at about 3\% a year. It was higher in the US and began to slow down in Britain for reasons economic historians continue to argue about. But the general trend was clear. And within this trend there was a steady move towards greater economic equality. But the crucial point is that this trend appears to have halted in the 1970's for reasons that are very much still in dispute. Both the broad strand of information society thinking and the development of socalled neo-liberalism were above all responses to this productivity crisis.

Thus the core of the debate about the realm of information, the role of information workers the nature of information societies was a search for renewed productivity growth of the economic growth based upon it. The reason everyone wanted to be like the United States and copy the so-called Anglo-Saxon model of neoliberal deregulation was that the US had higher levels of productivity. And this productivity growth appeared to be coming from the computing/telecommunications sector.

This lack of growth was, in my view, the main driver of the so-called crisis, because slowing productivity growth produced both a profits squeeze and a fiscal crisis of the state. There was a lot of spare cash around in the world looking for places to invest and it couldn't get adequate returns because of course it is productivity growth that eventually feeds through into sustainable returns. So this free capital was forced to pursue riskier and riskier investment, while at the same time the state, in order to keep growth going and thus sustain its tax base was pumping increasing amounts of money at low interest rates into the system.

So this remains an absolutely central problem and it is, in my view, the problem underlying how we understand what is happening to modern industrial societies and why then information sector was seen to be so important. Actually in my view the information sector compounded the problem. Your eyes are probably going to glaze over at this point, but one of the key problems is how you measure productivity. It is relatively easy to measure productivity in the production of widgets. You measure the inputs of fixed and working capital and labour and then measure how many more widgets were produced this year than last from the same inputs of capital and labour - that is fairly straightforward. When you have an 
immaterial product things become more difficult. With broadcasting for instance what is the amount produced? Is it hours of programming or number of viewers or number of advertising spots or value of advertising spots? And can you work on the basis of a standard product or does each program have a different value relating to some measure of quality. In short measures of productivity become increasingly arbitrary.

One of the side points is that when you get into the financial sector, it is measured in monetary terms. This means that if there is a bank that has a mortgage lending department, and in year one it is lending $£ 10$ billion and in year five it is lending $£ 100$ billion with the same level of staffing, then productivity growth is $1000 \%$ So its not surprising that in the financial boom productivity in the financial sector rises and in a financial crisis it suddenly collapses. It is purely a function of how things are measured. So that is just an illustration - this is actually a difficult thing to get your hands on, but it is what in my view underlies then whole debate.

\section{Christian Fuchs:}

What you're saying also has to do with the financialisation of the whole information economy. Part of this ideological discourse in the '90s about the high growth rate or the hope that was put into the growth of the information economy was also overlooking how financialisation drove this part of the so-called new economy. A finance bubble built up, exploded in 2000 and hit the Internet economy very hard.

It seems to me that something comparable is happening now. After the 2000 crisis Internet companies that troubles attracting new investors and venture capital. But then around 2004 and 2005, Facebook and similar companies started to emerge, Google became a publicly traded company, etc. A new ideology emerged: the idea of completely reinventing the Internet economy, and the strategy to "crowdsource" value creation to the users - the ideas of user-generated content, web 2.0, social media and so on. And what is now being hyped is the so-called social media economy as a new growth sector (Fuchs and Sandoval 2014b, Fuchs 2014a, c).

At the same time, what seems to be happening is that there's again a strong financialisation of this sector. Venture capital gets invested into social media, but the basic business model is targeted advertising. We know that out of 1000 targeted ads that are presented to users, they on average only click on one, which is in an extremely low rate (Fuchs 2014c, 115-116). It's difficult to actually make money on social media. The question is: Is a new financial bubble building up there based on the role of advertising and of financial investments?

Some readers may remember web platforms like boo.com, freeinternet.com, etoys.com, inktomi.com, pets.com, startups.com or theglobe.com, whose stock market values collapsed in the 2000 dot-com bubble. The rise of the concepts of social media and web 2.0 was partly a reaction to this crisis in order to try to restore investors' confidence. The IPOs of Google in 2004, Facebook in 2012 and Twitter in 2013 are indicative of the important role that venture capital and financialisation play in the social media economy. After the housing crisis unfolded in 2008, there was first a contraction of advertising expenditure that was then followed by a transfer from ad investments from the classical print sector to the online and social media sector. For many companies, social media due to its use of targeted advertising looks like a more secure investment realm than newspapers and print. The economic rise of social media is connected to the crisis of the print world.

The question is however if the largely advertising-based model of social media can last or if we are not experiencing the growth of a new financial bubble - a social media bubble - that at some point of time could explode. Google's stock price increased from around US $\$ 300$ in 2009 to more than US\$1,100 in 2014, Facebook's stock from around US $\$ 40$ in 2012 to more than US\$60 in 2014. This development forms however just one side of the social media economy. There is another one: After Twitter announced that its annual losses increased from US $\$ 80$ million in 2012 to US $\$ 645$ million in 2013, its stock value fell on February 6, 2014 , over night from US\$65 to US $\$ 50$. It has never made any profits, but has nonetheless decided to go on the stock market. Sina Weibo's stock value halved from a peak of around US\$135 in 2011 to US\$65 in February 2014. 
The advertising and information industries are highly volatile, high risk and uncertain economies: it is impossible to know, predict and calculate in advance if certain cultural goods or ads and the goods presented in them can be successfully sold. The social media economy is based on investors' belief that targeted advertising works. And the click-through-rate is on average just $0.1 \%$. And if users click on targeted ads, we do not know if such single clicks make them buy goods or not. In addition, more and more users find any form of online advertising annoying and use ad-block software and do-not-track cookies. If the belief that targeted ads work suddenly dwindles when for example one larger platform is in decline, the social media bubble may burst sooner or later. Bursting financial bubbles always have devastating social, political and economic effects. There are many reasons not to wait until the social media bubble bursts, but to start establishing and supporting alternatives to corporate social media.

Some of these companies might take a different strategy because of the peculiarities of the media economy. Because information is in reality a public good, it's more difficult to make profit with it - which results in the role of advertising, the building up of monopolies and so on, or also the strategy of trying to sell technologies which you need for accessing or producing information. So the question for these companies is also if they can survive based on the pure advertising finance model, or if some of them will move into other business sectors.

\section{Nicholas Garnham:}

I'm sure they will have to move into other business sectors, but this is not a new story is it? There has always been that link, sometimes closer than in other cases, between the selling of things and the selling of media content. That is why the BBC was set up originally. To sell radio sets. So that is not new. It is clear that you cannot finance all this out of advertising. So who will survive and with what business model? Who knows. What is striking is the speed with which things now come and go. So I don't think Google is about to go, but Microsoft is already on the way out. Will Facebook survive? I have some doubts. Twitter - probably come and go - or be bought by Google.

So as I say I don't think this is new. I think the speed of turnover is new. Who would have thought - those in the field - that Nokia would have disappeared? Very recently it had twothirds of the global market for mobile phones. Now it has virtually gone. So there is no rule in the world that any of these companies survive. I am old enough to remember when the big bogeyman was IBM. IBM was going to rule the world. IBM had a global monopoly in a key strategic sector. The European Commission spent years fighting against this monopoly. Where is IBM now? It hasn't gone. It is a nice little business. But no one now worries about it as a threat. So to this extent I think we can learn more from Schumpeter than we can from Marx so far as the information sector goes. That is how it works.

\section{Christian Fuchs:}

Yes, I think it shows the kind of high uncertainty that we have in the information economy.

\section{Nicholas Garnham:}

Yes, but it is in the economy in general. It is not just in the information economy. I get the impression that to people in cultural studies political economy just means latching on a bit of Marxism theory. But a very important part of political economy is industrial economics, the theory of the firm etc, and you can learn more about monopolisation from reading the classics of industrial economics than you can from Marx. So what we are talking about is a process and people forget, if they ever knew, that the reason Schumpeter wrote his original works was that he, like Keynes, like Hayek, was saying, "what do we do about the Depression? How do we get out of this slump?". And the problem for Schumpeter was that because of a process of oligarchisation, the profit rates were being driven to zero. This is what happens in markets if you allow them to work properly. The question therefore was, "What do you do about this?". Well for Schumpeter the answer was that the only thing you can do is create a new business and a new business sector which was not monopolised, in 
which there were still rents to be gained from a new product for which there was as yet no competition. That is why innovators and innovation are so important, which is why Schumpeter's economics have been central to work on then information society. People forget that in the 1970s and 80s the problem in the developed world was what do we do about capitalist stagnation? It was a real problem. And the Schumpeterian response was that we need innovation. You could create a completely new industry. But that industry too goes through the same cycle and so on ad infinitum. And that is what we see. It is just that the cycle has accelerated - there is no question about that. But these people and companies now ruling the world, the same will happen to them.

\section{Christian Fuchs:}

But one issue about Schumpeter's works is that there is a basic determinist assumption in it about business cycles and the long wave. So he thought we could calculate the moment when the crisis comes and that the long wave is always twenty-five years of upswing and then twenty-five years of down swing.

\section{Nicholas Garnham:}

But Schumpeter was not a long wave economist. Schumpeter was concerned with the business cycle but he was not a long waver. A lot of people in the information society debate were long wavers, particularly those at the Science Policy Research Unit at the University of Sussex around Christopher Freeman; they were explicitly long wavers. That is a different side of the argument, which was that capitalism has gone through a series of long cycles of development based on core technologies - basically steam power, electric power and information technology. That the effect of adopting these technologies takes about 30 to 40 years to work its way through the system and requires a complete reorganisation of institutions. The argument then was that this necessary and positive development of a new cycle of economic growth was being blocked in Britain by a number of institutional and cultural factors. But the great positive example they held up to the world was Japan. I am old enough to remember when not only these learned theorists - for whom I have a great deal of respect in fact even if they got this wrong - but policy makers in both Europe and the US were going round saying that Japan had found the answer, that if we didn't wake up and change swiftly Japan would be the ruling world economic power. What actually happened was that Japan entered a decade long slump from which they still have not recovered. What is then lesson I draw from this? That you want to be suspicious of people, who claim they have the definitive answer to the world's problems. That is the most important lesson. The second is that there is no single definitive answer. And the third is that you must always be ready for things to turn out differently from the way you expect. Schumpeter was not a determinist but he did say that you required a dynamic process of innovation and 'creative destruction' if you wanted to renew economic growth. Keynes argued on the other hand that state deficit financing and public works could lead to renewed growth. And Hayek argued for the deregulation of markets. The key point I want to make is that none of them were right and none of them were wrong. There is something to be aid for all of them as partial approaches to a specific historical problem, approaches which themselves change the nature of the problem and the outcomes of which all three would have agreed are inherently uncertain. There is not some great theory of the way the world works which, if only we knew it, we could tweak things and then everything would be wonderful.

That is my main argument with many of the versions of the return to Marxism today. They share exactly the same worldview as the so-called neo-liberals. They think there is one solution to the problem. One thinks that the market will solve everything, the other that doing away with the market will. Neither party seems to have more than the faintest inclining of how the world actually works or how much we know about it. Now all these economists Keynes, Schumpeter, Hayek were extremely intelligent people who had spent a lifetime studying the economy. Hayek himself, in spite of his intense disputes with Keynes, said when he died, "I may have disagreed with him, but he was the only genius I have ever known". They had a great respect for one another because they knew perfectly well that knowledge depends on 
the period. It depends on the problem you are addressing. There may be a short term solution to it or what looks like the best response to a problem at the time, but the notion that you have somehow fixed it - forget it.

\section{Christian Fuchs:}

Similar to the argument about the economic expectations about Japan that you mentioned, there are today many observers who say that China will soon become the world's dominant economic superpower because of its large growth rates. But the question is of course if this growth will last. China's economy is based on the export of a small number of products and a low-wage economy whose rise has also brought about a massive increase of inequality and internal political destabilisation.

I want to add something about Schumpeter: It of course depends on at which of his works you look and how, but I cannot really see that the problem with long-wave theory is only in the works of Christopher Freeman, Carolta Perez and similar figures. Assumptions about long-waves are immanent in Schumpeter's work themselves. So he is the starting point for the failures of long wave theory. Given the problems of instability, vulnerability, fluctuations, and problems to increase profitability in the financialised capitalist economy in the past decades, a new long wave based on the information technology paradigm simply did not emerge. Long wave theory is plainly wrong. French regulation theory faced a similar problem because after the crisis in the 1970s what they term a new mode of regulation simply did not emerge, although Aglietta, Lipietz, Boyer and others waited very long time for it.

In his early work The Theory of Economic Development, Schumpeter (1911) does indeed not propagate a theory of long waves. However, Nikolai Kondratieff published his book (Kondratieff 1925) about the long waves of the business cycle in 1925 and a major article about it in 1926 (Kondratieff 1926), which led Schumpeter to later celebrate Kondratieff's discovery and introduce the notion of the Kondratieff cycle as long wave.

Schumpeter (1939) describes the history of capitalism as a succession of long Kondratieff waves: 1787-1842, 1843-1897, 1897-. Each long wave would contain smaller cycles: "We now go on to postulate that each Kondratieff should contain an integral number of Juglars and each Jugular an integral number of Kitchins" (Schumpeter 1939, 180). He writes that his "schema" involves "speaking of a Long Wave" (Schumpeter 1939, 292) and even claims that the analysis of "long waves in economic activity [...] reveals the nature and mechanism of the capitalist process better than anything else" (Schumpeter 1943,67). So there you have the long wave concept in Schumpeter's works. Esben Sloth Andersen $(2009,193)$ in his study of Schumpeter as evolutionary economist argues that he "had a certain preference for the long waves".

Schumpeter says that there are "three classes of cycles, to which we shall refer simply as Kondratieffs, Juglars and Kitchins, because the average spans by which we choose to identify the individuals belonging to each of our three classes approximately correspond to the spans of the cycles 'discovered' by those three investigators, respectively" (Schumpeter 1939, 176). He also parallelizes long waves with technological innovations/revolutions: "Historically, the first Kondratieff covered by our material means the industrial revolution, including the protracted process of its absorption. We date it from the eighties of the eighteenth century to 1842 . The second stretches over what has been called the age of steam and steel. It runs its course between 1842 and 1897. And the third, the Kondratieff of electricity, chemistry, and motors, we date from 1898 on" (Schumpeter 1939, 178). "Each of them [the long waves, CF] consists of an 'industrial revolution' and the absorption of its effects" (Schumpeter 1939, 67). "These revolutions periodically reshape the existing structure of industry by introducing new methods of production - the mechanized factory, the electrified factory, chemical synthesis and the like; new commodities, such as railroad service, motorcars, electrical appliances; new forms of organization - the merger movement; new sources of supply - La Plata wool, American cotton, Katanga copper; new trade routes and markets to sell in and so on" (Schumpeter 1939, 68).

These quotations reveal that Schumpeter's economic theory is also a form of technological determinism: he causally reduces economic development to the technological 
forces of production without looking at the complex interactions of the whole mode of production, i.e. the class relations and the forces of production. So Schumpeter has indeed been important for economists who have made overarching and deterministic claims about the information economy and information technology. He has been their role model for a techno-deterministic economic theory that has been proven wrong by the facts of economic history.

Marx's ideas about technology's contradictions, the contradiction of the relations of production and productive forces, the general intellect, the role of knowledge in production and the telegraph in circulation, etc are much more insightful.

\section{Karl Marx and Capitalism}

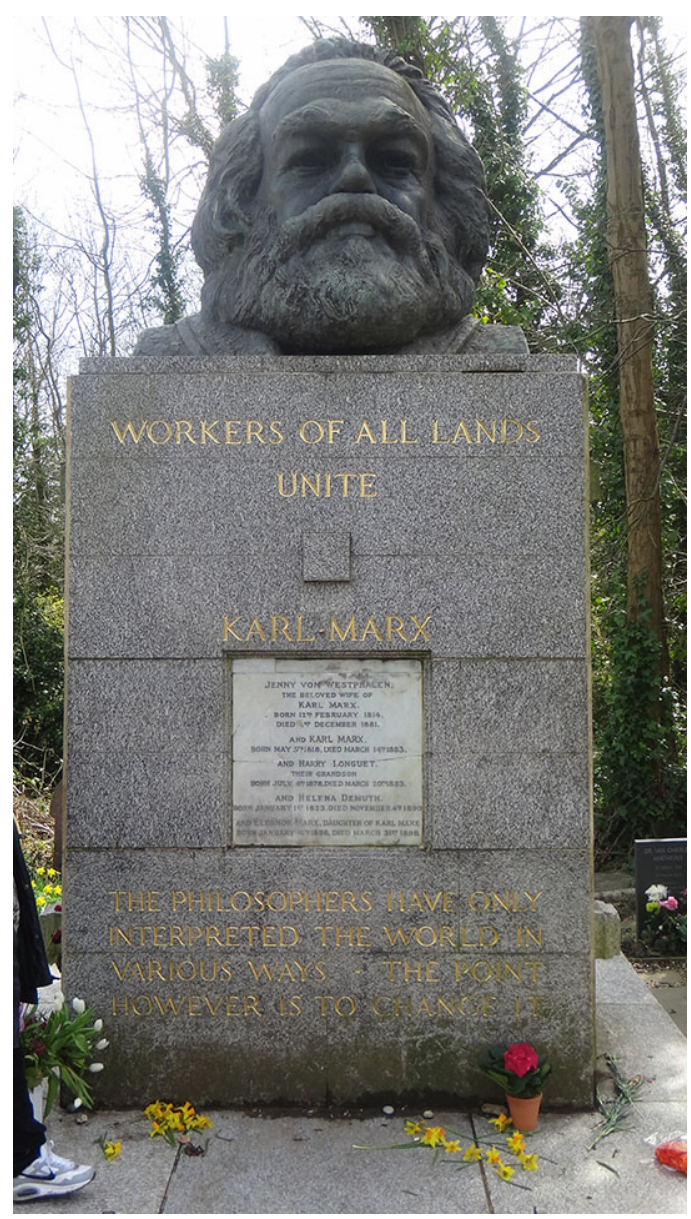

\section{Christian Fuchs:}

Since the new crisis of capitalism started in 2008 there has been a big interest in Marx's theory. There is a lot of scholarship inspired by Marx nowadays. David Harvey has published two companions to Marx's Capital (Harvey 2010, 2013) and has analysed the capitalist appropriation of urban commons and struggles for the right to the city (Harvey 2012). Michael Hardt and Antonio Negri $(2000,2004,2009)$ have based on a specific interpretation of Marx's Grundrisse published a trilogy of Empire, Multitude and Commonwealth that stresses the rise of what they term "immaterial labour" as new revolutionary force. Authors such as Alain Badiou (2010), Slavoj Žižek (Douzinas and Žižek 2010, Žižek 2013) and Jodi Dean (2012) have described new potentials for the communist idea and a communist movement. Terry Eagleton (2011) analysed what he considers to be 10 common prejudices against Marx and called for a discursive shift towards acknowledging that Marx was right.

In your 2011 contribution to the Handbook of Political Economy of Communication you argue that political economy nowadays, and political economy of communication, is, in your 
view, shaped by "a vague, crude and un-self-questioning form of Marxism, linked to a gestural and self-satisfied, if often paranoid, radicalism" that is based or underpinned by "a crude and unexamined romantic Marxist rejection of the market per se" (Garnham 2011, 42). So l'm wondering if you can follow up on this idea a little bit. How do you assess this return of Marx and the mentioned approaches?

\section{Nicholas Garnham:}

Well firstly I am always suspicious of returns because they are inherently conservative. The problem with this particular return is first that there is a tendency to treat Marxism as a belief system rather than a mode of analysis the validity of which depends upon testing it against reality. Thus in general the return is too uncritical of the Marxist tradition itself and doesn't pay sufficient attention to what is actually happening in the world. Thus by returning it seems to think it can bypass the history of both Marxism and that social and economic developments that have preceded the return and presumably require it. I am a great believer in Keynes's dictum "If the facts change I change my mind, what do you do?"

The first and most important thing is that what, in my it must be admitted cursory reading, all versions of the return to Marxism forget is Marx's positive evaluation of capitalism in historical terms. The upshot of that is the awful sanctimony of most of this writing - a sanctimony that I find much worse than distasteful. Whoever the writer he or she is concerned above all to demonstrate that they alone really feel for the world's poor and dispossessed and of course those who think differently don't. They then have to exaggerate the horrors of the world supposedly caused by capitalism. In actuality we have to recognise the fact that the welfare of most people in the world has improved - and for a lot of people improved considerably - quite consistently over the last 150 years, and this development shows no sign of reversing. So firstly I think it tends, for its own purposes, to exaggerate the horrors of the world. Now there is no doubt that there are horrors in the world. There is no doubt that there are many in the world being grotesquely exploited by any standards and many more living in dire conditions - but that has always been the case. The question is first whether this situation is worse than it would be without capitalism and second to what extent the horrors are caused by capitalism rather than for instance internecine conflicts of various sorts.

Another problem I have is the notion that it is all then problem of the market. The opposition to the market is dressed up as a straw man called "neo-liberalism". I don't think there ever was such a thing as neo-liberalism. There were certain people, who had different policy views based on different economic theories that favour, for various reasons, more market rather than less; but to lump them all together as neo-liberal is just lazy thinking. And it leads to this sort of Manichean thinking that on then one hand there is the market, but on the other there is - well what? Non-market, presumably. But what is this non-market? No one has been able to give me a convincing explanation within any major economic sphere what this non-market would actually be.

So that is my main criticism of the return to Marxism. I mean there are more detailed ones, the theory of alienation as the basis for a theory of exploitation, the usefulness of the labour theory of value and so on.

\section{Christian Fuchs:}

I think definitely one issue that Marx saw is that through accumulation historically ever more surplus is generated in capitalism. So the positive aspect of capitalism certainly is the overall increase of wealth in the world. And along with the development of the productive forces come potentials for reducing hard labour, increasing free time, and socialising the means of production. But these developments and potentials are antagonistically entangled into negative opposites and it is a positivistic misinterpretation when one reduces Marx's dialectic to the positive side. Marx (1867) in the chapters of Capital volume one, where he covers the historical tendencies of capitalist accumulation, sees that capitalism always means a struggle over the distribution of surplus. And so historically, the working class definitely has increased its absolute wealth, although there are a lot of people starving in the world. But I think what 
Marx wants to point us to is also the importance of looking at the relative distribution between those who control surplus and wealth and those who do not. And if we just look at the statistics - and this is what a lot of people inspired by Marx nowadays point out -, if you compare the nature of the class struggle and how its results are distributed between the capitalist class and the dependent class, then this means to measure in economies, or even globally, the relationship of the profit or capital share and the wage share. So the profit share is the share of profits in the world or in an economy in the GDP. The capital share is the share of an economy's total capital in the GDP. And you can do the same for the sum of wages, and then it's the wage share. We can see since the 1970s in most advanced economies how the wage share has gone down.

I obtained the GDP, net operating surplus (NOS) and the compensation of employees (COE) for the years 1960-2015 from the Annual Macro-Economic Database (AMECO) for a series of 26 countries: Australia, Austria, Belgium, Canada, Denmark, Finland, France, Germany, Greece, Iceland, Ireland, Italy, Japan, Korea, Luxembourg, Mexico, the Netherlands, New Zealand, Norway, Portugal, Spain, Sweden, Switzerland, Turkey, the United Kingdom, and the USA.

Marxist Political Economists have used such macro-economic statistical measures as approximations for Marx's notions of profit and variable capital in order to calculate profit rates (see for example: Brenner 1998, Shaikh 2000, Shaikh and Tonak 1994). I first calculated the wage shares (WS=COE/GDP) and the profit shares (PS=NOS/GDP) individually for each country and then derived the average values for all years. The capital share, i.e. the total share of the economy that is owned by the capitalist class, including profits and means of production, can be calculated as (CS=(GDP-COE)/GDP). The data allow calculating measures such as the average profit rate (profits/investment costs), the average capital share, the average profit share, the average wage share, or the average fixed capital share (share of fixed capital in the GDP) (see table 1).

\begin{tabular}{|c|c|c|c|c|c|c|c|c|c|c|c|}
\hline & 1960 & 1965 & 1970 & 1975 & 1980 & 1985 & 1990 & 1995 & 2000 & 2005 & 2010 \\
\hline $\begin{array}{c}\text { Average profit } \\
\text { rate }\end{array}$ & $58.6 \%$ & $50.8 \%$ & $47.2 \%$ & $36.8 \%$ & $35.6 \%$ & $38.8 \%$ & $37.9 \%$ & $38.1 \%$ & $38.3 \%$ & $38.3 \%$ & $35.8 \%$ \\
\hline $\begin{array}{c}\text { Average capital } \\
\text { share }\end{array}$ & $59.7 \%$ & $57.3 \%$ & $56.1 \%$ & $51.6 \%$ & $51.6 \%$ & $54.3 \%$ & $54.6 \%$ & $55.3 \%$ & $55.8 \%$ & $56.1 \%$ & $55.8 \%$ \\
\hline $\begin{array}{c}\text { Average profit } \\
\text { share }\end{array}$ & $39.3 \%$ & $36.5 \%$ & $34.3 \%$ & $29.5 \%$ & $29.5 \%$ & $31.3 \%$ & $30.7 \%$ & $31.1 \%$ & $31.0 \%$ & $31.1 \%$ & $30.0 \%$ \\
\hline $\begin{array}{c}\text { Average wage } \\
\text { share }\end{array}$ & $44.6 \%$ & $47.1 \%$ & $48.2 \%$ & $51.6 \%$ & $50.9 \%$ & $48.0 \%$ & $48.2 \%$ & $47.4 \%$ & $47.2 \%$ & $47.0 \%$ & $47.6 \%$ \\
\hline $\begin{array}{c}\text { Average fixed } \\
\text { capital share }\end{array}$ & $20.4 \%$ & $20.8 \%$ & $21.8 \%$ & $22.1 \%$ & $22.1 \%$ & $23.0 \%$ & $24.0 \%$ & $24.2 \%$ & $24.8 \%$ & $25.0 \%$ & $25.8 \%$ \\
\hline
\end{tabular}

Table 1: Average macroeconomic development in 26 countries

The data indicate that the profit share came to a low in the mid-1970s and since then somewhat increased and remained on average relatively constant. The average wage share strongly increased in the 1960s until the mid 1970s and then as a result of the capitalist class' attack on wages decreased subsequently by around $5 \%$. It was on average $51.6 \%$ in 1975 and only $47.0 \%$ in 2005 . The average capital share, i.e. the share of the economy owned by capitalists, increased from $51.6 \%$ in 1975 to $56.1 \%$ in 2005 . So wage repression and increased relative dispossession of the working class was an important feature of capitalism after the crisis of the mid 1970s. At the same time the average share of fixed capital increased from $20.4 \%$ in 1960 to $25.8 \%$ in 2010 . This is an indication that in relative terms the technification and computerisation of the economy has not cheapened production, but resulted in what Marx described as the rise of the organic composition of capital. Andrew Kliman (2012) shows the importance of the increase of the organic composition of capital in the USA and argues that the fast moral depreciation of computers (having to do with factors such as Moore's law in the context of market competition that compels companies to drive up productivity in order to survive) led to increased fixed costs. 
The profit rate is indirectly proportional to the organic composition of capital. Its rise means that the profit rate falls if there are no counteracting tendencies. The capitalist class by an attack on wages that lowered the wage share however hindered a dramatic fall of the profit rate by repressing wages. Since the mid-1970s, the average ownership share of capital in the economy increased, the profit rate stabilised, the average fixed constant capital rate continued rising, and wages fell relatively.

Anwar Shaikh $(2011,49 f)$ compared for the US "actual real wages since 1980 to the path they would have followed had they maintained their postwar relation to productivity. This departure from the trend was brought about through concerted attack on labour in this era". Shaikh's data do not show, as he argues, that after the stagflation crisis (1966-1982) there was a new US boom in 1982-2007. The US profit rate overall tended to remain more constant at a lower level than the 1960s, but also showed fluctuations. Shaikh's data show however that the profit rate would have fallen dramatically without wage repression. The search for ways to more strongly increase profits seems to have spurred financialisation.

The results of all these developments are inequality and crisis in contemporary capitalism - and that's why Marx is right. Both these phenomena are inherent to capitalism.

\section{Nicholas Garnham:}

That does not mean this is inequality. I think we need to make some important distinctions. First we have to distinguish within the profit share reinvestment money, tax revenues that go back in large part to social welfare, from what goes to the so-called controllers of wealth. Now one of the uncomfortable problems of modern capitalism is that it is true that there is a problem of distribution. The system we have at the moment actually distributes some of the surplus produced by workers in high productivity industries not to capitalists but to other workers. That is how the system of expanded consumption and production works.

It is true that there has been a problem of capital accumulation partly because of the problems we have already discussed - falling productivity and so on. So there has been an investment problem. A lot of profit has not been reinvested. It has gone into cash looking for high returns, it has gone into the financial sector - which was one of the reasons for the bubble. I am afraid it is just crude to see the wage/profit distinction as a sign of inequality. That workers are only getting wages and that capitalists are taking all the remaining surplus. That is not how a developed capitalist economy works. If you did not have any profits you would not have any reinvestment.

Now if you take a simple economic model and take capital ownership out of it - a cooperative for instance. The workers produce something and then sell it. Obviously they cannot take all the proceeds as consumption goods. If they are farmers they must keep back seed corn, buy fertilizer etc. Then what is spent on consumption goods - clothing, housing etc is in effect swapped with other workers. So that is the problem with the crude labour theory of value and a theory of exploitation based upon it. Everything is just divided down the middle between wages and profits. I am afraid I just do not buy that kind of analysis.

I agree that there has been an investment crisis, which is in part a problem of distribution - the shifting shares of the surplus going to capital and labour. I also agree that there is a very serious distribution problem as between surplus and deficit countries - and therefore between their respective work forces. I also agree that for reasons that I think are not fully understood, but seem to be related to the shift towards services and knowledge work there has been a shift within returns to labour towards a small skill/knowledge elite and away from routine, semi-skilled labour. This shift certainly produces increased inequality, but has little to do with the relative shares of the surplus going to capital and labour. But most people recognise these problems. You don't have to be Marxist to do that. The question is whether a Marxist analysis gives you a better understanding of the nature of the problem and possible solutions to it.

\section{Christian Fuchs:}

Let me add one thing to what I said: In the end political economy has to look at ownership. And capital that is re-invested is certainly not owned by workers, but by shareholders, private 
owners and banks to whom companies pay interest. You are right in saying that it matters if one measures profits before or after taxes and if there is a re-distribution via the state from capital to labour or the other way round. In the data I used the data for profits are after indirect taxes, but before direct taxes. But what would happen if one deduces the direct taxes? Do they benefit the working class' share of the economy? The answer is no, to the contrary, as I will argue in a minute.

Net operating surplus measures profits after indirect taxes (such as VAT), but includes corporate income taxes and interest payments. The interests paid remains within the capitalist class, albeit there is a transfer from non-financial to financial capital. In the EU 27 countries, corporate taxes accounted in 2013 for only $0.3 \%$ of the GDP (data source: AMECO). In the United States the value was $0 \%$, meaning that treated as a collective capitalist, companies in the USA do not pay taxes (data source: AMECO). Data indicates that capital taxation has since the 1970s in general been low in European and North American capitalism, reaching never up to $1 \%$ of the GDP of a country and varying in most countries between 0 and $0.3 \%$ of the GDP (data source: AMECO). The rise of neoliberalism has resulted in a subsequent lowering of capital taxation in both the UK and the USA. European and North American tax regimes are friends of capitalist interests and have supported the neoliberal class struggle of capital against labour. Given low capital taxation, there have hardly been redistributive effects from capital to labour via the welfare and tax system.

Thanasis Maniatis (2014) has in a recent empirical analysis shown that it is a myth that the state has in the past decades benefited labour. He calculated the development of the net social wage - defined as "the benefits in cash and in kind received by workers from state expenditures minus the total taxes paid by those workers to the state" (Maniatis 2014, 16) in the United States, Canada, UK and New Zealand for the years 1952-1997. He shows that there is no re-distributive effect of the state from capital to labour in any of these countries. The situation differs and is particularly bad for workers in the USA, but overall he found simply no indication that the state benefits workers' wages in these countries. He concludes that "labor loses everywhere from fiscal redistribution" and that "it is likely to lose much more in countries like the United States where it is organizationally and politically weaker" (Maniatis 2014, 33). As political economist of communication we need to look at actual data in order to see how capitalism has developed.

In terms of the crisis, the structural problems of accumulation that we have been discussing are one issue. But what has also been happening since the 1970's is the huge increase of household debt, which has to do with wage repression and relates back to the stagnation of wages and the wage sum. In the USA, the share of home mortgages in the GDP increased from $13.9 \%$ in 1949 to $26.2 \%$ in $1970,31.0 \%$ in $1980,41.3 \%$ in $1990,45.9 \%$ in $2000,66.6 \%$ in 2005 , and $72.7 \%$ in 2008 (data source: Federal Reserve Economic Data, FRED: HHMSDODNS_GDP). The share of consumer debt in the GDP simultaneously increased from $7.1 \%$ in 1949 to $12.2 \%$ in $1970,13.7 \%$ in $1990,16.6 \%$ in $2000,17.3 \%$ in 2005, and $18.2 \%$ in 2008 (data source: Federal Reserve Economic Data, FRED: HCCSDODNS_GDP). So private household debt calculated as a combination of consumer and mortgage debt stood in 2008 at $90.9 \%$ of the GDP. At the same time, the US-wage share decreased from $58.1 \%$ in 1970 to $55.9 \%$ in 1990 and $54.2 \%$ in 2005 (data source: calculations based on AMECO). Private household debt's share in personal income was in $2007130 \%$ in the USA and 100\% in the Eurozone (FT Online, Markets Insight: Europe and US Lines Cross on Household Debt Ratio. May 9, 2013).

And if people don't have enough money available for buying consumer goods, of course what they do is to take out loans, to get credit cards and use them for consumption purposes, and to remortgage private homes. And coupled with the financial economy, this has turned into a financial derivative itself. Debt was turned into a financial derivative itself. So it seems to me we cannot really explain the crisis without taking the problem of wage repression and its impacts into account. 
Nicholas Garnham:

I am not sure that is the right way of looking at it. If wages had been somewhat higher would household debt have been lower? I doubt it. But the more important point is that the relationship between wages and credit is more complex than that. Household debt has to be seen as a form of the wage. Yes within a capitalist economy there has always been a contradiction between maximising the return to capital as against labour on the one hand and ensuring buoyant consumption to ensure expanded reproduction on the other. This has then been managed historically by the development of credit and by state deficit financing of consumption. So I don't think anyone denies the existence of the problems to which you point, from whatever school of economic thought they come. The problem is how do you get round it? What alternative forms of distribution would you have? In my view crude forms of Marxism do not give you any answer to that question, because they are assuming that it is all about class struggle at the point of production. That if you force up wages and reduce the profit share you will solve the problem. Well you clearly wouldn't. If you did what happens?

It is the problem with cooperatives. The problem with cooperatives if they are successful is that workers keep for themselves too much of the general surplus. This is not desirable. You get very privileged groups who just happen to be in a good place - like landowners, for instance or bankers who have a hold on a particular tap and make excess rents out of it. And this can also happen to workers. Indeed it is often forgotten that the much-reviled bankers are workers - one of the main groups they have been stealing from are bank shareholders. So you have to have a system of distribution that gets round this. It is the problem Stalin had with the Kulaks.

It is true that, after a long historical period in which the trend within capitalism was towards greater distributional equality by raising the wage share, the last couple of decades have seen a reversal of that trend. The reasons for that reversal are in dispute as is the optimum wage/profit split to ensure expanded reproduction. I am afraid the whole of this discussion has been skewed by a debate about bankers' pay and the fortunes of Russian oligarchs. These great extremes of wealth are distasteful, they make people angry - that is understood. But they are irrelevant to how the economy works and to broad patterns of distribution within it. People say, "Abramovich has an income equivalent to the GDP of 16 countries. It's disgraceful, we must do away with the market". Frankly that is just kiddie economics.

\section{Christian Fuchs:}

Going back to the data I mentioned, one sees the average wage share of the 26 included countries decreased from $51.6 \%$ in 1975 to $47.0 \%$ in 2005 . So what neoliberalism actually did is a perfect form of class struggle so that the wage share in a lot of countries was repressed.

\section{Nicholas Garnham:}

I am not clear that so-called neoliberalism caused this trend. They were there before. Neoliberalism was in part a response to that situation. It wasn't the cause of it. I think we need to be clear about this. It is the same debate about deregulation. One of the reasons for the growth of neoliberalism/monetarism/the deregulatory trend was precisely how do you deal with stagnating growth. That was the problem. Some people may have seen it as a way of repressing wage rates and in some cases it may have been a cause of repressed wage rates But I return to the central question; even if that is the case, it does not seem to me to be a very good way of measuring the efficiency or other wise of the general production of welfare of the existing capitalist system. You still have to respond. Given what is happening at the moment, what policy, what different form of economic organisation would you propose to change that distribution so that there continues to be an expanding economy in the sense of spreading welfare more widely and deeply throughout the world? That is the challenge. And none of the so-called returns to Marxism that I have read have any credible response to that challenge. 
Christian Fuchs:

The one question is if and how to further expand the production of the surplus product, and the other is the question of distribution of surplus and wealth. So what capitalism, to a certain extent, has been successful at is to increase the absolute wealth; but what it has been historically, I mean over 100/150/200 years, been incapable of is to stabilise the distribution at a level so that the majority of people in the world can have a decent living. That's why capitalism is the problem and needs to be replaced by communism.

\section{Nicholas Garnham:}

What you have said simply isn't true. It is not a question of stabilising because it requires, still, expansion. You will either reduce - which is perfectly possible - the standard of living of the "advanced" world - or whatever you want to call them - the better off countries in the world to the level of the then less well off, or you will have to expand such that those rise roughly to the level we have at the moment, if that is possible within environmental constraints. Let us assume for the moment that it is. So, what you have to produce is an economy that expands and redistributes at the same time. On the whole, that is what capitalism has done. Less well in some places, more slowly perhaps than it might have done. If you want an alternative you have to have, therefore, a system which will go on doing that better than what is happening at the moment.

\section{Christian Fuchs:}

I think that the challenge is probably how to further increase the absolute production of wealth. But capitalism is not doing well in terms of distribution at the global and the national level. There is no fair distribution, but lots of inequality.

\section{Nicholas Garnham:}

This is where we get to the nub of then problem, the crisis. It is the question of "what is the surplus?". We now come back to the productivity problem and the shift to the service sector. It is not at all clear what the surplus is once you get into services, and in terms of distribution it is clearly much more sticky. It is difficult to distribute this kind of surplus which may have to do with cultural facilities and what Amartya Sen has called capabilities. Let us take healthcare systems as an example. They are increasingly dragging in resources and becoming relatively more expensive. But you cannot produce a healthcare surplus for wider distribution. People keep on thinking there might be a technological fix. But actually the problem in the end is that you need highly trained doctors and other healthcare workers and highly specialised medical equipment, which in turn requires highly skilled people etc build and operate. And you need increasingly specialised drugs. And so on. To spread these benefits around is not easy and it certainly cannot be done under the slogan "we must ramp up productivity". You cannot ramp up productivity in health care. That is why healthcare systems everywhere in the world are in crisis.

\section{Christian Fuchs:}

Healthcare is a good example, but for healthcare, where it is still publicly organised, the problem is funding. And of course in times of neoliberal austerity, states are not taxing companies more, but they have given tax payers money to banks in order to bail them out, and at the same time there is not enough money for public services. I think that the crisis of public services today is a to a significant amount a crisis of states not taxing companies. Look for example at Greece, where the public health care budget was cut by $40 \%$ in the course of austerity measures and as a consequence the number of people saying they are not able to afford medicine they need has dramatically risen ${ }^{5}$. Budget crises of the state have to do with the level of public services that is afforded or avoided.

\footnotetext{
${ }^{5}$ Compare: Stuckler, David and Sanjay Basu. 2013. Europe's Public Health Disaster. How Austerity Kills. CNN Online. September 9, 2013. http://edition.cnn.com/2013/09/09/business/europes-public-health-disaster-how-austerity-kills/. See
} 
Nicholas Garnham:

It clearly isn't because the answer is that the crisis in public health, to take one example, is a crisis whether it is organised on a private sector basis, a totally public sector basis, as, broadly speaking, in the UK, a state-funded insurance basis as in France. Moreover this problem is not new. In the UK within 18 months of the NHS being founded Aneurin Bevan not noted as a neo-liberal - was arguing in the House of Commons that it could not be afforded. The notion that if you hadn't bailed out the banks the NHS would have all the money it requires to meet the demands upon it is just fantasy. Fantasy.

\section{Christian Fuchs:}

That is not what I am saying. What I am saying is that there is virtually no capital taxation since the 1970s, and that is the problem. And we must tax corporations to a larger extent. And then the state has money.

\section{Nicholas Garnham:}

Corporation tax is of course only one way of taxing returns from capital. The part it should play is a matter for detailed debate within debates about fiscal policy. But it is certainly true that the state has been facing a long-standing fiscal crisis. There is no question that it has become increasingly difficult to extract enough tax revenue to meet the expectations of voters, let alone their real needs, however those might be defined. This is a problem throughout the developed world. So how would your communist system solve this problem? Can you tell me what this communist system is going to look like?

\section{Christian Fuchs:}

You cannot exactly plan how an alternative system will look in advance. Theodor W. Adorno (2005, 287f) once wrote, "One continually finds the word critique, if it is tolerated at all, accompanied by the word constructive. The insinuation is that only someone can practice critique who can propose something better than what is being criticized; Lessing derided this two hundred years ago in aesthetics. By making the positive a condition for it, critique is tamed from the very beginning and loses its vehemence. [...] This should be opposed by the idea, in a variation of a famous proposition of Spinoza, that the false, once determinately known and precisely expressed, is already an index of what is right and better" (Adorno 287f). The argument that critics must be able to have a fully devised architecture of alternatives is often used for arguing that there is no alternative and that alternatives should not even be attempted.

\section{Nicholas Garnham:}

What do you mean you cannot plan? You have got to plan it. You must have some idea what it will look like in advance.

\section{Christian Fuchs:}

I think it will be a worker-controlled economy coupled with parliamentary democracy.

\section{Nicholas Garnham:}

But how will worker-controlled companies get over the problems I was talking about concerning cooperatives? How will you stop worker elites forming? How will you manage to tax them successfully and make sure you get enough of the surplus out of them? That was the problem Stalin had with the Kulaks - it is a very old problem. People who control a certain part of the productive apparatus, if it is working well, are very unwilling to give up their surplus to be spent on someone else, unfortunately. It might be nice, but they are very

also: Karanikolos et al. (2013). 
resistant. So you still have to find a mechanism for doing it. What is your mechanism going to be?

Christian Fuchs:

The interesting thing is that we can today see in the course of the crisis a turn towards cooperatives and self-managed forms of organisation. Especially in countries like Greece and Spain. So it seems to be something that people are thinking about in the situation of crisis. There are many examples of cooperatives formed in the course of the crisis in diverse sectors such as farming and food processing ${ }^{6}$, finance, industry, retail, knowledge ${ }^{7}$, organic household cleaning products ${ }^{8}$, spicery ${ }^{9}$, credit unions ${ }^{10}$, software coops and worker-owned tech collectives ${ }^{11}$, etc. These examples from different realms of economic production such as agriculture and farming, industry, retail, banking, knowledge and software production, show that co-operatives have the potential to defy the crisis, create and defend jobs, and democratise production and ownership ${ }^{12}$. Worker-controlled cooperatives are a start for practicing communism in the here-and-now - a form of immanent transcendence that aims at developing potentials and germs of an economy beyond capitalism.

\section{Nicholas Garnham:}

Our current coalition government, when they first came in were very keen on supporting this, especially the Liberal Democrats. And there is undoubtedly a place for them in our current economy. But they will not solve the overall problem of distribution of the surplus within current capitalist economies. So I come back to the key point. How would you solve it?

\section{Christian Fuchs:}

I think there is no easy answer to it, but going from here to there of course is a long way. The question is what can be the measures of the political Left that it can demand and if it is in power implement immediately; so things like a basic income, increasing capital taxation at a harmonised level within Europe. So I think in the end the biggest issue is to bring back corporate taxation.

\section{Nicholas Garnham:}

The harmonisation and indeed increase of corporation taxation is not a demand of the Left. It is the demand at present of a range of governments, including the current US government. They are trying to do this. Of course they are trying to do it. So who is this Left demand being addressed to? People who are not doing it? All the leading governments at the moment are

${ }^{6}$ The Observer Online. Spain's Communist Model Village. October 20, 2013.

http://www.theguardian.com/world/2013/oct/20/marinaleda-spanish-communist-village-utopia

${ }^{7}$ BBC News Online. Basque Co-operative Mondragon Defies Spain Slump.

http://www.bbc.co.uk/news/world-europe-19213425

${ }^{8}$ The Tyee. A Co-operative Response to the Greek Crisis. From the Rubble Comes Bio Me, the Country's First Worker-Run Factory. October 17, 2013. http://thetyee.ca/Life/2013/10/17/Greek-CrisisResponse/

${ }^{9}$ Red Gold: Saffron Cooperative Thrives amid Greek Crisis. Spiegel Online International. April 11, 2013. http://www.spiegel.de/international/europe/saffron-farming-cooperative-thrives-in-greecedespite-crisis-a-893527.html

${ }^{10}$ How the Banking Crash Sparked a Credit Union Boom. Guardian Online. October 8, 2012.

http://www.theguardian.com/commentisfree/2012/oct/08/banking-crash-credit-union-boom

${ }^{11}$ Software coops and worker-owned tech collectives:

http://p2pfoundation.net/Free_Software_Cooperatives, http://p2pfoundation.net/Worker-

Owned_Tech_Collectives

${ }_{12}$ Co-operation an Alternative to Austerity, says Co-operative Expert. November 6, 2012. Guardian

Professional Online. http://www.theguardian.com/social-enterprise-network/2012/nov/06/co-operationalternative-austerity

Together - How Cooperatives Show Resilience to the Crisis. Documentary Film. CECOP-CICOPA. http://www.together-thedocumentary.coop/ 
trying to reach consensus so they can deal with this problem of corporate taxation, led by the US as it happens.

Christian Fuchs:

Yes, that is a good development but it hasn't been implemented.

Nicholas Garnham:

That is true, but not for want of trying. It is actually difficult to implement.

\section{Christian Fuchs:}

It's very difficult, yes. Maybe we here have to also come also back to Habermas (2013), who has the idea of trans-nationalising the public sphere, exactly out of these problems of how to tax corporations. Habermas (2013) has the idea of harmonising the fiscal policies and taxation policies at a European level. So possibly at the political level we must go away from the regulation at the level of nation states.

Habermas (2013) in an article responded recently to Wolfgang Streeck (2013), Director of the Max Planck Institute for the Study of Societies, who argued that as response to austerity measures, one should shrink Europe and revert to nation states in order to defend the remaining rests of welfare states. Habermas argues that the EU's response to the crisis is the development of an "expertocracy" without any real consequences. Habermas (2013) continues, "The handling of the Cyprus crisis when it was no longer a matter of rescuing each country's own banks suddenly demonstrated that those who had caused the crisis could indeed be called to account instead of the taxpayers and that state budgets encumbered with debts could be brought back into line through increases in revenues just as much as through cuts in expenditures. However, only an institutional framework for joint European fiscal, economic, and social policy would realize a necessary presupposition for the possible elimination of the structural defect of a suboptimal monetary union. Only a common European effort, not the unreasonable abstract expectation that national competitiveness could be improved through each country's own efforts, can promote progress toward the overdue modernization of outmoded economic structures and clientelistic administrative structures".

\section{Nicholas Garnham:}

But what we are talking about is already being harmonised, or they are trying to harmonise it at a global level through the G8, the European Union etc. The leading OECD countries, led in this case by the US, strongly supported by the UK government, are trying to get harmonised trans-national corporate tax regimes. Of course they are trying because they are losing revenues that they want and need. This is not some kind of capitalist conspiracy. This is capitalist governments - supposedly in the old jargon - trying to get their hands on corporations like Google and Amazon etc. The EU is already doing this. You don't need some transnational public sphere to get this done, I can assure you.

Christian Fuchs:

Then we could say that in this realm of taxation, there is already a reflection about transnationalising taxation.

\section{Discussion}

\section{Sylvia Harvey:}

I'm sorry that your discussion seems to have got rather locked down. And one simple thing to say would be, can you please start working to put the $P$ back in the $E$, that is the politics in economics. Nicholas said earlier on that he wanted to get out of the iron cage constructed by Weber, so let's move on now and say let's get out of the iron cage. I agree with a great deal of what Nicholas said, not all of what he said, but about the developmental power of capitalism. China seems to be an extraordinary example of that, where capitalism has 
created more wealth and, to some extent, distributed that through the world; although in the rich parts of the world, the Global North, the value of peoples' wages seems to be going down. So, George Osborne makes a speech in Europe and says that, briefly, you have to cap the unsustainable social democratic agreement in Europe ${ }^{13}$. Well, sooner or later that will cause political problems. Anyway, I invite you to find a way out of this iron cage that you constructed.

\section{Richard Paterson:}

Can I take Nick back to the early 1980 s - this is something he did not mention, when he was part of the GLC (Greater London Council) - and reflect on his interventions then and basically the basis on which those interventions were being made, because they were really political interventions; to basically follow on from Sylvia's comment. If there's a political intervention today that is necessary, my own interest at the moment is in the area of intellectual property rights, and so I want to ask him to consider what interventions are needed in relation to the communications industries in terms of the way in which the surplus from the exploitation, the distribution and exploitation of content, is used and where the monies actually go. Can you sort of reflect on political intervention back then and political interventions that are appropriate today?

\section{Steven Barnett:}

My question follows on from both Sylvia and Richard, but it's sort of broader; which is, is there actually a failure, a growing failure of politics? I will accept your analysis - as Sylvia does - of the development benefits of capitalism. But I think there's a broader issue, which is if you accept that and you accept the way in which individual capitalism has actually benefitted large sections of the population, there is the other side of that coin, which is not the Marxist side or the Communist side, which is the hard edges, the sometimes brutal effects of capitalism, which requires political intervention, not to overthrow it, but simply to mitigate the worst excesses. And I would argue that if you look not just at communications, but at energy, utilities, for example, if you look at the growth of a company like Google, there is a growing sense of political impotence or, at the very least, a political inability or unwillingness to act, which is actually causing those edges of the worst impacts of capitalism, making it more brutal. And I don't see any end to that; I only see it getting worse. I just wondered how you'd react to that.

\section{Nicholas Garnham:}

I will answer Steven and Sylvia's together and then come back to Richard's.

In terms of mitigating the hard edges, it seems to me, in general, that one has to do it and argue for it on a case-by-case basis. It depends where the shoe is rubbing, who is causing it and so on.

But I think, with your reference to energy policy, Google etc you raise a much larger issue, which is the future of social democracy. It is one of the criticisms I have of Tony Judt's late book III Fares the Land (2010). The nostalgia for a world that was led him to neglect the political problems that social democracy, for all its very real achievements, had thrown up. The move to deregulate came at least in part from voters, citizens who felt increasingly that bureaucratised state monopolies were not responsive to their needs. That the man in Whitehall did not know best. People now forget that a key motivator of Habermas's early work on the public sphere and on the lifeworld was growing political opposition from within the Left broadly conceived to what was seen as the alienating nature of the institutions of the welfare state. We can see the same thing in Foucault's work. Increasingly critics saw social democracy as creating, through the exercise or soft power, a new form of authoritarianism. Indeed I see this as a key strand in New Left thinking and one of the sources of cultural studies. Welfare was seen as a new form of repression, more insidious than economic

${ }^{13}$ Extract from the Chancellor's Speech to the Open Europe Conference:

https://www.gov.uk/government/speeches/extracts-from-the-chancellors-speech-on-europe 
repression. The focus of critique shifted from the factory and the labour market to hospitals, mental institutions, prisons etc. I am sure you are all familiar with that argument which was certainly very central to British debates over social policy in the 1970's and lead very directly into many aspects of New Labourism.

But I think there is another side to social democracy to which less attention has been paid, but which has been laid bare by the crisis. We see this now in the British energy situation. It seems to me that one of the trends that led into the crisis was that, far from a set of politicians imposing on their voters neo-liberal policies in favour of capitalists or property owners or whatever, there was a kind of devil's pact between the electorate and politicians politicians promising the electorate solutions to life's problems which in fact they could not deliver, but the voters were not going to vote for them unless they though they would deliver them. And this then lead to an increasing upping of the ante, such that we have actually talked ourselves into a situation, where the productive economy doesn't produce enough to pay for the life style the electorate now expects governments to deliver. I am afraid I do not regard that as a Right wing position. I think it just happens to be the reality. And rapidly growing household debt is part of that problem. Governments of whatever shade of political opinion were too frightened to attempt to curb that debt or to tell their electorates that their expectations could not be met. It is not that we are not taxing corporations enough, but that we have had - still have - a political system that is complicit in not facing up to a range of social problems.

Now if you take the energy sector, one of the reasons the energy sector is having problems is that there are so many different constituencies that have to be squared - the people who don't want nuclear power, the people who don't want wind power, the people who don't want fracking etc - that it is very difficult to have a coherent policy. And so they put sticking plasters on it. And one of the sticking plasters is, "we will get capital investment if we free the market". But then you've got to regulate the market and, not surprisingly, it blows up in the politicians' faces. It was a foreseeable result, but also one which was perfectly understandable, given the political context that people got themselves into. I think the same thing has happened with healthcare.

\section{Steven Barnett:}

But you wouldn't argue that the end result, the best result would be complete absence of all regulation

\section{Nicholas Garnham:}

Of course not. The answer in the present situation might well be a return to a state-run monopoly. But I think that is a pragmatic question. Not an ideological question. And it is a difficult practical question. Then trouble is that well-intentioned and well-informed people have different answers. That is the other thing I would say on all this, that the notion that there is some easy answer and that it is some nasty people in their own interests who are standing in the way of the optimum solution is not the way the world actually works.

Now the question of where the surplus goes in the system. I don't have any expertise in intellectual property law, except to know that it is either very simple or very complicated and I am not sure which. That is to say you probably have to have some intellectual property law. The free software model cannot be generalised. If you tried some version of the Tragedy of the Commons might result. Intellectual property law is in general utilised by certain interests to gain through rents more than their fair share of the surplus. But if you don't have such a law you might not have a surplus at all. So it is part of the wider problem of what kind of funding systems and systems of distribution do you set up form these types of immaterial activity which are very difficult to monetise, to define exactly what the product is etc. It is clear, and this has always been the case, that it is the control of key distribution mechanisms that allows the extraction of rents. It used to be broadcasters themselves; then it became telecoms and cable companies; but now it is largely Google and its sub clones, because everything has to go through that system. It is a very difficult problem to solve. I am not sure it has changed; it has just shifted from one choke point to another. 
I have not had anything to do with communications policy for a long time, so I had assumed that now, if you were studying the digital economy, intellectual property would be a central issue.

\section{Christian Fuchs:}

What is interesting in the debate is that the political issue seems to be all about the relationship of the capitalist economy and the state: What role can and should the state play? And that is interlinked with debates about globalisation. But an idea you were just bringing in yourself now is that maybe we must rethink the issue of state control of key parts of the economy - which is a fairly old socialist idea - but one that might be very important today.

Already Marx and Engels $(1848,3)$ formulated in 1848 as a demand of the first German Communist Party (Bund der Kommunisten, 1847-1852): "Princely and other feudal estates, together with mines, pits, and so forth, shall become the property of the state. The estates shall be cultivated on a large scale and with the most up-to-date scientific devices in the interests of the whole of society. [...] All the means of transport, railways, canals, steamships, roads, the posts etc. shall be taken over by the state. They shall become the property of the state and shall be placed free at the disposal of the impecunious classes". Other demands included for example universal free education, strong progressive taxation combined with an abolition of flat, indirect consumption taxes, free legal services, the replacement of private banks by a state bank in order to regulate the credit system, the complete separation of Church and State, the curtailment of inheritance rights, and stateorganised social security.

\section{Nicholas Garnham:}

It was not necessarily a socialist idea. In the United Sates the tradition of state regulation and/or operation of key monopolies came out of populism and corporatism. So I do not think that state control of key utilities is necessarily a socialist response. And if you are going to move in that direction you have to be aware - and not hide behind some general ideological notion of neo-liberalism - of why these state monopolies were broken up and de- or reregulated. It was not because someone had an idea that they would make money out of the process. It was much more complicated than that. There were real pressures on actually managing and organising them. Many people who were, if you like, in favour of public service and were inside those corporations realised that they were becoming, in that form, unmanageable. So I am not saying that it would be easy to go backwards. And if you go backwards you need to be aware of that pre-history, and not simply reinvent the wheel and then come to same impasse.

\section{Hilary Wainwright:}

I was a bit sad that the discussion about culture sort of got lost and got a bit overwhelmed by the subject of economics, because I was interested in the role of social culture and collaborative culture in economic change - and maybe this will lead back to the GLC. It has to do with really the significance of the cultural changes of the ' $60 \mathrm{~s}$ and '70s, the rebellions of the '60s and '70s. And obviously Boltanski and Chiapello (2007) discussed this. And one indication of capitalism was its incredible capacity to appropriate those energies, which came from outside both corporations and the market in the sense of the corporate-dominated market. Okay, there were other things in the markets and I think we still have to make those distinctions; but that energy, that creativity, collaborative creativity came from outside the market and outside the state, and capitalism was able to sort of appropriate it and, as Boltanski and Chiapello (2007) argue, separate cultural energies from the social critique.

Maybe there's a Raymond Williams dimension to this, which is that whole idea of structure of feeling (Williams 1977, 128-135), the idea of changes in process that are not articulated alternatives, but are kind of new cultural intuitions, emotions, which he sums up with "feeling". But precisely because they aren't articulated and institutionalised that they can be appropriated; so I think his idea helps to understand that process of appropriation. So in a way now there's a sort of crisis of that creative capitalism which was underpinned by credit 
and financialization. Now given that is sort of beginning to implode, are the conditions there for reconnecting the cultural energy/cultural critique/cultural alternative and visions and the material and the economic/social critique?

The way I was involved in the GLC was that we were trying to fuse that social critique, that redistributive framework which the GLC was, with a kind of emphasis on collaborative creativity and a kind of regeneration of the economy and its productivity, but within a social framework rather than a purely capitalist one. Are there conditions now under which that could be emerging? I mean, I suppose if you look at the whole sphere of cultural production, you can see the emergence of new forms of production, the peer-to-peer, collaborative, cooperative form, that is sometimes more competitive, more productive than the corporations. You know you can see it with Google and in some way they've had to rely on open software and the sort of new, non-capitalistic forms, in a way, for their own capacity. So, if the Left and the Trade Unions and all the kind of agencies of progressive change were more alert to the forms emerging kind of within capitalism that encapsulate this creativity, almost reconnecting with the ' 60 s and ' 70 s ethos as an economic driver. I don't know if there's anything you can sort of observe on these issues?

\section{Bruce Robinson:}

Well, it's not so much a question as a bit of a challenge about what the modern market would look like, and it follows on a bit from the last point. If you think the market basically has to allocate resources by giving information in monetary terms through the exchange relationships and so on, do we not now have the sort of technology that enables that flow of information to occur without going through a market form? In other words, doesn't the information technology we have today have the potential for an alternative to the market in terms of providing those flows of information, of economic information? And have we therefore already created, to a large extent, the basis for some form of non-market economy? It seems to me that there are already indications, in the way in which some capitalist firms are using these systems, that they are moving towards something like that in terms of planning, just-in-time systems and so on. Do you see that as being a possibility? Or what would be your objections to that as a form of non-market?

\section{Nicholas Garnham:}

I can remember when there was a huge amount of excitement about the cybernetic society in the 1960's and experiments which were actually done in Chile under Allende. Chile was seen as a small enough economy that you could actually computerise the whole thing. It was a fantasy at the time. And I suspect it remains a fantasy now.

But the real problem with your suggestion is that markets do not distribute economic information per se but a specific type of information, namely aggregated relative valuations. So it regulates exchange values. This information flow doesn't have to move into a physical monetary form. Indeed a large proportion of market transactions are now in computerised form. So what you are proposing in fact already exists. It is the modern form of the market.

\section{Christian Fuchs:}

My personal opinion on this is that the Internet shows us exactly how right Marx was in terms of the contradiction between the forces of production and the relations of production (Fuchs 2008, chapter 7). So following up on your question, I think what Marx saw was really how capitalist production socialises the forces of production, but remains trapped within class relations. I think that's exactly what we also see on the Internet today: the antagonism between productive forces and class relations of production. Of course, there are all forms of online commodification. But on the other hand, we have things that are non-market based and produce a kind of economy of the commons, where information is treated as a common good. Something like Wikipedia is not a market at all, but the basic use value of encyclopaedic knowledge is voluntarily produced as a common good. And it works that people engage in this economy. They do not need a market for it. So I think Wikipedia is the communist version of the Internet (Fuchs 2014c, chapter 10). And now extrapolate Wikipedia 
to society and you have a communist economy.

Charles Brown:

I was struck by what Nicholas was saying about discussing neoliberalism, seeing neoliberal governments as somehow acting on behalf of the national capitalist classes or whatever. But picking up on various points that we've had in this discussion, isn't it precisely the characteristic of neoliberalism, that actually the economic and the political become severed in many ways? The problem for many governments is that what becomes powerful is the corporation and/or economic interests, so it becomes increasingly difficult for governments of all stripe to actually effectively regulate, to effectively intervene. And what happens is democracy effectively gets hollowed out.

\section{Nicholas Garnham:}

That clearly is one side of what has been loosely called neoliberalism. But there are clearly other strands. You have people who see the growth of oligopoly and large global corporations as the problem and their solution is various forms of competition law to break them up. For instance you get an alliance between some neoliberals and those on the Left who would like to split up the banks. So it is not a simple picture. So what is called neoliberalism is not a unified position and the policy responses are different and often come out of different political situations. In the US neoliberal policy was a response to the stagflation of the 1970's against a background of state regulation of utilities and the financial sector, which came out of populism and the New Deal and within a federal system. In Britain Thatcherism and then New Labour, the British versions of neo-liberalism came out of the long standing "condition of Britain debate", a debate that in fact started at the end of the $19^{\text {th }}$ century, concerning Britain's relative economic lag versus in particular the US, but also in the post war period Western Europe. There were Left responses to this question and there were Right responses. And in each case there were great internal differences.

But what I come back to, and you may see this as a refrain, is that it has become increasingly clear to me that one always needs to understand to what problems the "neoliberal" agenda was a response. All these developments have roots and were a response to real problems. Certainly It does not make sense to analyse these developments in the way for instance that someone like Perry Anderson does, writing from an Olympian height that capital does this or capital does that, or the capitalists class does this or that. Capital doesn't do anything. It is a theoretical construct for analysing something. Nor as a concrete historical actor is there a coherent capitalist class. So these are all, in their different contexts, responses to given problems to be judged on their merits as such responses; just as the long history of the creation of the European Community and then the European Union were a response to the problem of "how do we stop war in Europe?". Things followed from that among which were elements of what could be called a neo-liberal agenda.

There are historical ironies in all these arguments. I can remember when, I suppose, I saw myself as a member of the Left of the Labour Party - a Bennite - when I voted against entry to the European Community because it was seen as a capitalist conspiracy to liberalise markets. Now it is the neo-liberals who want to come out and its some of the surviving social democrats, maybe, who think its perhaps not such a bad idea. So these things turn around but the point is that there is always a particular historical political context in which these developments take place. And they are not in general well explained by imposing some general political-economic or other theory on them. I think they all need to be analysed quite carefully but with an awareness of the very small room for manoeuvre that human organisations always actually have, and the awareness that the problem being addressed may not be the real problem.

What I take, I have to say, from my theoretical and political career over the last 50 years, I suppose, is that on the whole we were all arguing about the wrong problem. What was really going on was something different, and it was things like shifting demographics, changes in family structures, changes in the composition of the work force and so on. That it was these deeper currents that made the difference for better or worse. Most of the things we were 
fighting about, it did not matter whether we won or lost the argument, to be honest. I don't think it would have made much difference to the very different world in which we now live.

One final point in relation to this. The discussion we have been having has been in part about a return to Marxism and a response to the crisis. This return and this response is usually couched in terms of what the Left should do. But the distinction between Right and Left seems to me to be an almost entirely meaningless historical hangover. I can think of no important political problem the responses to which one can usefully distinguish in terms of Right and Left. It really is time not to return to anything but to move on.

\section{References}

Adorno, Theodor W. 2005. Critical Models: Interventions and Catchwords. New York: Columbia University Press.

Andersen, Esben Sloth. 2009. Schumpeter's Evolutionary Economics. A Theoretical, Historical and Statistical Analysis of the Engine of Capitalism. London: Anthem Press.

Badiou, Alain. 2010. The Communist Hypothesis. London: Verso.

Bell, Daniel. 1974. The Coming of Post-Industrial Society. London: Heinemann.

Boltanski, Luc. 2011. On Critique. A Sociology of Emancipation. Cambridge: Polity Press.

Boltanski, Luc, and Éve Chiapello. 2007. The New Spirit of Capitalism. London: Verso.

Boltanski, Luc and Axel Honneth. 2009. Soziologie der Kritik oder Kritische Theorie? In Was ist Kritik?, eds. Rachel Jaeggi and Tilo Wesche, 81-114. Frankfurt am Main: Suhrkamp.

Bourdieu, Pierre. 1980a. A Diagram of Social Position and Life-Style.Media, Culture \& Society 2 (3): 255-259.

Bourdieu, Pierre. 1980b. The Aristocracy of Culture. Media, Culture \& Society 2 (3): 225-254.

Bourdieu, Pierre. 1980c. The Production of Belief: Contribution to an Economy of Symbolic Goods. Media, Culture \& Society 2 (3): 261-293.

Bourdieu, Pierre. 1984. Distinction. A Social Critique of the Judgement of Taste.Cambridge, MA: Harvard University Press.

Bourdieu, Pierre et al. 1996. Photography. A Middle-brow Art. Stanford, CA: Stanford University Press.

Bourdieu, Pierre, Alain Darbel and Dominique Schnapper. 1997. The Love of Art: European Art Museums and Their Public. Cambridge: Polity Press.

Brenner, Robert. 1998. The Economics of Global Turbulence. New Left Review 229: 1-265.

Castells, Manuel. 1996. The Rise of the Network Society. The Information Age: Economy, Society, and Culture. Volume I. Malden, MA: Blackwell

Castells, Manuel. 1997. The Power of Identity. The Information Age: Economy, Society, and Culture. Volume II. Malden, MA: Blackwell.

Castells, Manuel. 1998. End of Millennium. The Information Age: Economy, Society, and Culture. Volume III. Malden, MA: Blackwell.

Collins, Richard, Nicholas Garnham and Gareth Locksley. 1988. The Economics of Television. The UK Case.London: Sage.

Dean, Jodi. 2012. The communist horizon. London: Verso.

Douzinas, Costas and SlavojŽižek, eds. 2010. The Idea of Communism. London: Verso.

Eagleton, Terry. 2011. Why Marx Was Right. New Haven, CT: Yale University Press.

Fraser, Nancy and Axel Honneth. 2003. Redistribution or Recognition? A Political-Philosophical Exchange. London: Verso.

Fuchs, Christian. 2008. Internet and Society: Social Theory in the Information Age. New York: Routledge.

Fuchs, Christian. 2011. Foundations of Critical Media and Information Studies. New York: Routledge.

Fuchs, Christian. 2014a. Critique of the Political Economy of Informational Capitalism and Social Media. In Critique, Social media and the Information Society, eds. Christian Fuchs and Marisol Sandoval, 51-65. New York: Routledge

Fuchs, Christian. 2014b. Digital Labour and Karl Marx. New York: Routledge.

Fuchs, Christian. 2014c. Social Media: A Critical Introduction. London: Sage.

Fuchs, Christian. 2014d. Theorising and Analysing Digital Labour: From Global Value Chains to Modes of Production. The Political Economy of Communication 2 (1): 3-27.

Fuchs, Christian and Marisol Sandoval. 2014a. Digital Workers of the World Unite! A Framework for Critically Theorising and Analysing Digital Labour. tripleC: Communication, Capitalism \& Critique 12 (forthcoming): Special Issue: Philosophers of the World Unite! Theorizing Digital Labour and Virtual Work: Definitions, Forms and Transformations, eds. Marisol Sandoval, Christian Fuchs, 
Jernej A. Prodnik, Sebastian Sevignani and Thomas Allmer.

Fuchs, Christian and Marisol Sandoval. 2014b. Introduction: Critique, Social Media and the Information Society in the Age of Capitalist Crisis. In Critique, Social Media and the Information Society, eds. Christian Fuchs and Marisol Sandoval, 2-47. New York: Routledge.

Gandy, Oscar H. jr. 1995. Introduction to the Colloquy. Critical Studies in Mass Communication 12 (1): 60-61.

Garnham, Nicholas. 1978. The Structures of Television. London: British Film Institute. Revised edition.

Garnham, Nicholas. 1979. Contribution to a Political Economy of Mass Communication. Media, Culture \& Society 1 (2): 123-146.

Garnham, Nicholas. 1983. Toward a Theory of Cultural Materialism. Journal of Communication 33 (3): 314-329.

Garnham, Nicholas. 1986. Extended Review: Bourdieu's Distinction. The Sociological Review 34 (2): 423-433

Garnham, Nicholas. 1988. Raymond Williams, 1921-1988: A Cultural Analyst, A Distinctive Tradition. Journal of Communication 38 (4): 123-131.

Garnham, Nicholas. 1990. Capitalism and Communication. Global Culture and the Economics of Information. London: Sage.

Garnham, Nicholas. 1995a. Political Economy and Cultural Studies.Reconciliation or Divorce?Critical Studies in Mass Communication 12 (1): 62-71.

Garnham, Nicholas. 1995b. Reply to Grossberg and Carey. Critical Studies in Mass Communication 12 (1): 95-100.

Garnham, Nicholas. 1998. Information Society Theory as Ideology: A Critique. LoisiretSociété 21 (1): $97-120$.

Garnham, Nicholas. 2000a. Emancipation, the Media and Modernity. Oxford: Oxford University Press.

Garnham, Nicholas. 2000b. "Information Society" as Theory or Ideology?A Critical Perspective in Technology, Education and Employment in the Information Age.Information, Communication \& Society 3 (2): 139-152.

Garnham, Nicholas. 2004. Contradiction, Confusion and Hubris. A Critical Review of European Information Society Policy. In Contradiction, Confusion and Hubris. A Critical Review of European Information Society Policy, ed. Pascal Verhoest, 6-18. Montpellier: ENCIP.

Garnham, Nicholas. 2005. From Cultural to Creative Industries. International Journal of Cultural Policy 11 (1): 15-29.

Garnham, Nicholas. 2008. From Cultural to Creative Industries. The Political Economy of Culture and Cultural Policy.Ruskin Annual Lecture.Association for Heterodox Economics 10th Anniversary Conference. Anglia Ruskin University. Cambridge. July 3rd, 2008.

Garnham, Nicholas. 2011. The Political Economy of Communication Revisited. In The Handbook of Political Economy of Communications, eds. Janet Wasko, Graham Murdock and Helena Sousa, 41-61. Malden, MA: Wiley-Blackwell.

Garnham, Nicholas and Raymond Williams. 1980. Pierre Bourdieu and the Sociology of Culture: An Introduction. Media, Culture \& Society 2 (3): 209-223.

Grossberg, Lawrence. 1995. Cultural Studies vs. Political Economy. Is Anybody Else Bored with this Debate? Critical Studies in Mass Communication 12 (1): 72-81.

Grossberg, Lawrence. 2010. Cultural Studies in the Future Tense. Durham, MA: Duke University Press.

Habermas, Jürgen. 1968. Arbeit und Interaktion. Bemerkungen zu Hegels Jensener "Philosophie des Geisters". In Technik und Wissenschaft als "Ideologie", 9-47. Frankfurt am Main: Suhrkamp.

Habermas, Jürgen. 1976. Zur Rekonstruktion des Historischen Materialismus. Frankfurt am Main: Suhrkamp.

Habermas, Jürgen. 1984. The Theory of Communicative Action. Volume 1. Boston, MA: Beacon Press.

Habermas, Jürgen. 1987. The Theory of Communicative Action. Volume 2. Boston, MA: Beacon Press.

Habermas, Jürgen. 2004. Wahrheit und Rechtfertigung. Frankfurt am Main: Suhrkamp.

Habermas, Jürgen. 2013. Demokratie oder Kapitalismus? Vom Elend der nationalstaatlichen Fragmentierung in einer kapitalistisch integrierten Weltgesellschaft. Blätter für deutsche und internationale Politik 5 (2013): 71-79 [English translation, online:

http://www.resetdoc.org/story/00000022337]

Hardt, Michael and Antonio Negri. 2000. Empire. Cambridge, MA: Harvard University Press.

Hardt, Michael and Antonio Negri. 2004. Multitude. New York: Penguin Books, 
Hardt, Michael and Antonio Negri. 2009. Commonwealth. Cambridge, MA: Belknap Press.

Hartley, John. 2012. Digital Futures for Cultural and Media Studies. Chichester: Wiley-Blackwell.

Harvey, David. 2010. A Companion to Marx's Capital. London: Verso.

Harvey, David. 2012. Rebel Cities. From the Right to the City to the Urban Revolution. London: Verso.

Harvey, David. 2013. A Companion to Marx's Capital Volume 2. London: Verso.

Hegel, Georg Wilhelm Friedrich. 1803/1804. Jenaer Systementwürfe I. Hamburg: Felix Meiner Verlag.

Hegel, Georg Wilhelm Friedrich. 1805/1806. Jenaer Systementwürfe III. Hamburg: Felix Meiner Verlag.

Honneth, Axel. 2007. Pathologien der Vernunft: Geschichte und Gegenwart der Kritischen Theorie.

Frankfurt am Main: Suhrkamp.

Jessop, Bob and Stijn Oosterlynck. 2008. Cultural Political Economy: On Making the Cultural Turn without Falling into Soft Economic Sociology. Geoforum 39 (3): 1155-1169.

Judt, Tony. 1992. Past Imperfect: French Intellectuals 1944-56. New York: New York University Press.

Judt, Tony. 2010. III Fares the Land. London: Penguin.

Karanikolos, Marina et al. 2013. Financial Crisis, Austerity, and Health in Europe. The Lancet 381 (9874): 1323-1331.

Kliman, Andrew. 2012. The Failure of Capitalist Production. Underlying Causes of the Great Recession. London: Pluto Press.

Kondratieff, Nikolai D. 1925. The Long Wave Cycle. New York: Richardson \& Snyder.

Kondratieff, Nikolai D. 1926. Die langen Wellen der Konjunktur. Archiv für Sozialwissenschaft und Sozialpolitik 56: 573-609.

Machlup, Fritz. 1962. The Production and Distribution of Knowledge in the United States. Princeton, $\mathrm{NJ}$ : Princeton University Press.

Marx, Karl. 1857/58. Grundrisse. London: Penguin.

Marx, Karl. 1867. Capital. Volume I. London: Penguin.

Marx, Karl and Friedrich Engels. 1848. Demands of the Communist Party in Germany. In MECW, Volume 7, 3. London: Lawrence \& Wishart.

Maniatis, Thanasis. 2014. Does the state benefit labor? A cross-country comparison of the net social wage. Review of Radical Political Economics 46 (1): 15-35.

Miller, Toby. 2011. Cultural Studies in an Indicative Mode. Communication and Critical/Cultural Studies 8 (3): 319-322.

Sandoval, Marisol. 2013. Foxconned Labour as the Dark Side of the Information Age: Working Conditions at Apple's Contract Manufacturers in China. tripleC: Communication, Capitalism \& Critique 11 (2): 318-347.

Scannell, Paddy. 2007. An Interview with Professor Paddy Scannell, conducted by TarikSabry in Oxford in July 2006. Westminster Papers in Communication and Culture 4 (2): 3-23.

Schumpeter, Joseph A. 1911. The Theory of Economic Development. New Brunswick, NJ: Transaction Publishers.

Schumpeter, Joseph A. 1939. Business Cycles. A Theoretical, Historical and Statistical Analysis of the Capitalist Process. Abridged. New York: McGraw-Hill.

Schumpeter, Joseph A. 1943. Capitalism, Socialism \& Democracy. London: Routledge.

Shaikh, Anwar. 2000. Explaining the Global Economic Crisis. Historical Materialism 5 (1): 103-144.

Shaikh, Anwar. 2011. The First Great Depression of the $21^{\text {st }}$ Century. Socialist Register 47: 44-63.

Shaikh, Anwar M. and E. Ahmet Tonak. 1994. Measuring the Wealth of Nations. Cambridge: Cambridge University Press.

Streeck, Wolfgang. 2013. Was nun, Europa? Kapitalismus ohne Demokratie oder Demokratie ohne Kapitalismus. Blätter für deutsche und internationale Politik 4 (2013): 57-68.

Sum, Ngai-Ling and Bob Jessop. 2013. Towards a Cultural Political Economy. Putting Culture in its Place in Political Economy. Cheltenham: Edward Elgar.

Williams, Raymond. 1977. Marxism and Literature. Oxford: Oxford University Press.

Williams, Raymond. 1989. What I Came to Say. London: Hutchinson Radius.

Žižek, Slavoj, ed. 2013. The Idea of Communism 2. London: Verso.

\section{About the Authors}

After studying English Literature at Cambridge University, Nicholas Garnham worked from 1963-70 in Television as film editor and film director. He joined the Polytechnic of Central London (that is now the University of Westminster) in 1972 to teach filmmaking and film theory. In 1974 he was made head of the newly created Department of Communications and headed the team that created the first Media 
Studies degree in the UK in 1975. He is founding editor of the journal Media, Culture and Society. In 1986 he founded the Centre for Communication and Information Studies (CCIS) - that today is the Communication and Media Research Institute (CAMRI) - and remained its director until he retired from the University of Westminster in 2002. In 1987 he started with William Melody the annual European Communication Policy Research Conference. Since 2002, Nicholas Garnham is Emeritus Professor of Media Studies, University of Westminster.

Christian Fuchs is Professor of Social Media at the University of Westminster's Communication and Media Research Institute and the Centre for Social Media Research. He is the editor of the journal tripleC: Communication, Capitalism \& Critique (http://www.triple-c.at), chair of the European Sociological Association's Research Network 18 - Sociology of Communications and Media Research, Vice Chair of the EU COST Action "Dynamics of Virtual Work" and author of books such as "Social Media: A Critical Introduction" (Sage 2014), "Digital Labour and Karl Marx" (Routledge 2014) and "Foundations of Critical Media and Information Studies" (Routledge 2011).

http://fuchs.uti.at, Twitter: @fuchschristian 